This work is licensed under a Creative Commons Attribution 4.0 International License.

Ovaj rad dostupan je za upotrebu pod međunarodnom licencom Creative Commons Attribution 4.0.

https://doi.org/10.31820/f.31.2.17

Jakob Patekar

\title{
PRIHVATLJIVOST PREVEDENICA KAO ZAMJENA ZA ANGLIZME
}

dr.sc.Jakob Patekar, RIT Croatia, jakob.patekar@outlook.com,Dubrovnik

prethodno priopćenje

UDK 811.163.42'373.45:811.163.42

rukopis primljen: 7. kolovoza 2019; prihvaćen za tisak: 5. prosinca 2019.

Početkom se 21. stoljeća u Hrvatskoj zamjećuje promjena diskursa - ne govori se više o posudivanju iz engleskoga već o prodiranju toga jezika u hrvatski. Doba interneta i elektroničkih medija omogućilo je da govornici hrvatskoga dolaze u kontakt s riječima iz engleskoga jezika neposrednije i mnogo brže nego prije te da engleske riječi brzo uključuju u svoju komunikaciju. Dio je jezikoslovaca ali $i$ drugih stručnjaka, poput lektora, podigao uzbunu da je hrvatski jezik pod opsadom engleskoga te su kao jedan vid obrane počeli nuditi zamjenske, hrvatske riječi za anglizme. Cilj je ovoga rada istražiti stavove govornika hrvatskoga jezika spram anglizama i pripadajućih prevedenica. $U$ radu se stoga na temelju mrežnoga upitnika koji je ispunilo 1340 sudionika sagledava prihvatljivost određenoga broja hrvatskih zamjena za anglizme. Analiziraju se usto $i$ razlozi sudionika za uporabu anglizma naspram prevedenica te obratno. Kvantitativna je i kvalitativna analiza pokazala da postoje razlike u prihvatljivosti pojedinih zamjenskih riječi za anglizme te da govornici imaju različite razloge zašto prednost daju engleskoj odnosno hrvatskoj inačici. Zaključuje se da pri osmišljavanju prevedenica anglizama i oblikovanju hrvatske jezične politike u obzir svakako treba uzeti stavove govornika kao jedan od važnih čimbenika.

Ključne riječi: anglizmi; prevedenice; norma; uzus; purizam; jezična politika 


\section{Uvod}

U drugoj je polovici 20. stoljeća kontakt hrvatskoga i engleskoga jezika opisivan „posuđivanjem” iz engleskoga (npr. Filipović 1986: 15), što je početkom 21. stoljeća uvelike zamijenjeno "nasrtajima”, „prijetnjama” (Težak 2004: 5-6) i „prodorom” (Babić 2004: 213) engleskoga jezika. Očita promjena diskursa odnosno jezika kojim opisujemo kontakt tih dvaju jezika govori mnogo promijenjenim okolnostima te o odnosu - ili percepciji odnosa - tih jezika. Hrvatski jezik nije više taj koji je činitelj, koji posuđuje, već je primatelj, onaj na koji se nasrće, onaj koji je pod prijetnjom, onaj u koji se prodire. Tomu je zasigurno pridonijela činjenica da je doba interneta $\mathrm{i}$ elektroničkih medija omogućilo da govornici hrvatskoga dolaze u kontakt $s$ riječima iz engleskoga jezika neposrednije i mnogo brže nego prije te da engleske riječi brzo uključuju u svoju komunikaciju. U strahu od prodora engleskoga jezika, dio je jezikoslovaca i drugih stručnjaka započeo s obranom u vidu osmišljavanja zamjenskih riječi za udomaćene i nove anglizme; iz jezičnih savjetnika u 21. stoljeću iščezavaju srbizmi, a njihovo mjesto zauzimaju anglizmi.

Sve veća prisutnost engleskoga jezika u pogledu posuđenica nije obilježje samo hrvatskoga jezika; naime, ista je pojava zabilježena u brojnim drugim jezicima (Muhvić-Dimanovski 2004: 142) i to u tolikoj mjeri da postoje imena tzv. hibridnih jezika: „hrengleski, Deutschlish/Gerlish, Dutchlish, franglais/ Frenglish, Italglish/itangliano, Russlish, Spanglish/englañol i Swenglish" (Drljača Margić 2009: 66). U tim se jezicima utjecaj engleskoga jezika ne ogleda samo na leksičkoj razini, već i na drugim razinama, poput pragmatičke i sintaktičke te u svim funkcionalnim stilovima.

U Hrvatskoj je utjecaj engleskoga jezika na hrvatski, pa tako i u vidu anglizama, također zabilježen u raznim područjima i funkcionalnim stilovima (npr. Bogunović i Ćoso 2013, Brdar 2010, Drljača 2006, Drljača Margić 2009, Filipović 1990, Gradečak-Erdeljić i Varga 2009, Horvat i Štebih Golub 2010, Hudeček i Mihaljević 2005, Hudeček i Mihaljević 2009, Mihaljević 1999, Opačić 2007, Peti-Stantić, Tušek i Horniš 2009, Pritchard 1996, Škifić i Mustapić 2012, Nikolić-Hoyt 2009, Sočanac 2009, Vilke i Medved Krajnović 2006 itd.).

Nadalje, čini se da ne postoji medij u Hrvatskoj koji u posljednjih petnaest godina nije pisao o ugrozi koju engleski jezik predstavlja za hrvatski, od dnevnih novina do brojnih portala, što upućuje na popularnost pojave i izvan jezikoslovlja; u nastavku je nekolicina naslova: 
„Ima li hrvatski jezik šanse preživjeti?” (Telegram.hr, 3. kolovoza 2018.)

„Anglizmi dojadili i Ustavnom sudu: 'outsorcing', 'spin off' i 'start up’ postaju prošlost?” (Vijesti.hr, 10. travnja 2015.)

„Borba protiv 'rogobatnih' tuđica: Jezikoslovci izabrali najomraženiji anglizam u Hrvata” (Dnevnik.hr, 17. ožujka 2015.)

„Lajkamo, hejtamo i degradiramo hrvatski jezik” (Novi list, 6. siječnja 2013.)

„Poplava engleskih riječi u hrvatskom jeziku” (Srednja.hr, 8. prosinca 2012.)

„Hrvatski jezik više nije 'cool”' (Jutarnji list, 22. veljače 2006.)

Jasno je, dakle, da engleske riječi u hrvatskome jeziku zanimaju i struku i javnost. No, postavlja se pitanje koliko struka pri oblikovanju jezične politike, u ovome slučaju pri osmišljavanju zamjenskih riječi za anglizme, u obzir uzima stavove onih koji se jezikom koriste. Kao što su prepoznale Muhvić-Dimanovski i Skelin Horvat (2008: 2-3), „[v]ećinom su jezikoslovci i ljudi koje barem donekle zanimaju terminološka pitanja ti koji odlučuju je li riječ prihvatljiva te koja od predloženih novotvorenica treba dobiti 'zeleno svjetlo', a koja ne" (autorov prijevod). Pored toga, ono što nedostaje u znanstvenome opisu i promišljanju anglizama u hrvatskome jeziku jesu stavovi govornika o anglizmima odnosno njihovim zamjenama. $\mathrm{Na}$ to upućuju i Muhvić-Dimanovski i Skelin Horvat (2008: 14), na čiji ćemo se rad vratiti u teorijskome dijelu. Pojedini autori nagađaju da je veća uporaba anglizama rezultat lijenosti, pomodarstva ili pak "sluganskoga” (Opačić 2012: 6) odnosno „kolonijalnoga mentaliteta” (Babić 2004: 215-216) hrvatskih govornika, no činjenica jest da te govornike nitko nije upitao zašto upotrebljavaju riječ iz engleskoga radije negoli iz hrvatskoga jezika.

Cilj je ovoga rada stoga ispitati stavove govornika hrvatskoga jezika spram anglizama i pripadajućih prevedenica. U teorijskome se dijelu bavimo terminologijom, odabranim anglizmima i prevedenicama te prethodnim istraživanjima, u metodologiji pored cilja navodimo i istraživačka pitanja te opisujemo instrument, provedbu i sadržaj istraživanja, a u rezultatima donosimo obrađene podatke iz kvantitativne i kvalitativne analize. U diskusiji obrazlažemo rezultate te u konačnici u zaključku izvodimo implikacije i dajemo smjernice vezano uz anglizme i njihove zamjene u hrvatskome jeziku. 


\section{Teorijska pozadina}

\subsection{Terminologija}

S obzirom na bogatstvo nazivlja u vezi s jezičnim posuđivanjem (v. Muhvić-Dimanovski i Skelin Horvat 2006), valja na samome početku pojasniti da se anglizmi u ovome radu smatraju riječima iz engleskoga jezika bez obzira na njihov stupanj prilagodbe ili mogući jezik posrednik. Dakle, riječ je o posuđenicama koje su prilagođenice ili tuđice (usp. Drljača 2006: 69; Muhvić-Dimanovski i Skelin Horvat 2006: 206).

Kada je riječ o hrvatskim zamjenama ponuđenim u ovome istraživanju, možemo govoriti o prevedenicama. Razvrstavanje tih petnaest riječi u uobičajenih šest kategorija (v. Muhvić-Dimanovski i Skelin Horvat 2006: 207) nije nužno, a moguće je da za neke od njih ne bismo mogli ni odrediti kojoj točno kategoriji pripadaju (v. Muhvić-Dimanovski 1992: 128-129). Ipak, valja istaknuti razliku između dviju glavnih skupina prevedenica u ovome radu. Prva jesu zamjene u vidu riječi koje već postoje u hrvatskome jeziku, ili se zamjena sastoji od takvih riječi, a kojima je pridodano novo značenje, primjerice poveznica za engl. link ili oluja ideja za engl. brainstorming. Prema tradicionalnoj bi podjeli poveznica pripadala kategoriji „semantičkih posuđenica" (Muhvić-Dimanovski 1992: 125), dok oluja ideja ne bi ulazila u tu već u kategoriju „frazeološkoga kalka” (Muhvić-Dimanovski 1992: 126127). Druga skupina zamjenskih riječi jesu kalkovi slikokaz za engl. slide i višezadaćnost za engl. multitasking, a gdje se radi o riječima koje se sastoje od poznatih elemenata iz hrvatskoga jezika. U tradicionalnoj bi podijeli kalkovi bili dijelom „formalno nezavisnih neologizama” Muhvić-Dimanovski (1992: 128), no ta kategorija uključuje kalkove poput raketoplana za engl. space shuttle, ali i riječi i izraze koji nisu nužno kalkovi, npr. sjedeći protest za engl. sit-in. Iz upravo opisanih razloga izbjegavamo svrstavanje u uobičajene kategorije te svih petnaest riječi nazivamo prevedenicama.

\subsection{Prethodna istraživanja}

Kao što smo naveli u uvodnome dijelu rada, anglizmi su dobro opisana pojava u hrvatskome jeziku. Ipak, od brojnih istraživanja tek se nekolicina bavi stavovima govornika vezano uz anglizme i prevedenice, a ovdje ćemo navesti četiri najrelevantnija.

Muhvić-Dimanovski i Skelin Horvat (2008) u svome su istraživanju o natjecanjima za nove riječi analizirali i ono koje se održava u Hrvatskoj na 
inicijativu časopisa Jezik te su proučile reakcije sudionika hrvatskih i bosanskohercegovačkih internetskih foruma na to natjecanje i na njemu ponuđene riječi. Autorice smatraju da su internetski forumi bogat izvor podataka jer sudionici slobodno izlažu svoje mišljenje sigurni u svojoj anonimnosti i slobodni od utjecaja jezičnih stručnjaka i institucija. Isto tako navode da ni u istraživanjima neologizama u drugim zemljama, a tako ni u Hrvatskoj, nisu naišle na slučajeve ispitivanja stavova vezanih uz novotvorenice, pa tako ni na kakvu metodologiju istraživanja.

Autorice na temelju analize forumskih komentara zaključuju da je većina sudionika natječaj za novom riječju doživjelo kao purističko nastojanje, što jedni vide pozitivno, a drugi negativno, kao i riječi koje su na natječaju ponuđene. Muhvić-Dimanovski i Skelin Horvat (2008) uočile su da su sudionici novotvorenice analizirali sa stajališta razumljivosti, tvorbenosti i semantičke logike te stoga smatraju te da su sudionici u svojim internetskim raspravama pokazali da imaju intuitivan osjećaj za ono što je prihvatljivo odnosno neprihvatljivo u jeziku. Pored toga, autorice su prepoznale da su sudionici svjesni da treba vremena da nove riječi uđu u jezik. Konačno, autorice su nerijetko naišle na humoristične i ironične komentare.

Drljača Margić (2012) provela je istraživanje na uzorku od 244 studenta na Sveučilištu u Rijeci ispitujući njihove stavove prema zaštiti hrvatskoga jezika od utjecaja engleskoga i prema promicanju hrvatskih zamjena za anglizme. Autorica je upotrijebila upitnik kojemu je osim stavova ispitala poznavanje hrvatskih zamjena za osamnaest anglizama (npr. handout, internet, hardver, budžet, bypass itd.) tražeći od sudionika da upišu prevedenicu. Rezultati su istraživanja pokazali da $65 \%$ sudionika ne zna zamjene ili misli da ne postoje. Sudionici su istraživanja bili otvoreni ideji hrvatskih zamjena, ali očito s njima nisu bili dovoljno upoznati te su smatrali da je potrebna bolja promidžba tih riječi u vidu češće uporabe hrvatskih zamjena u medijima. Određene su zamjene doživjeli neprirodnima, nezgrapnima, nepotrebnima i isforsiranima, i to u onim slučajevima kada na te zamjene nisu bili naviknuti. Konačno, 80 \% sudionika „podržava paralelnu uporabu anglizama i njihovih zamjena jer osjećaju značenjsku i(li) stilističku razliku među izrazima, odnosno anglizme doživljavaju neformalnijima od njihovih hrvatskih ekvivalenata" (391).

Matić (2015) je ispitala stavove 78 studenata prve godine Računarstva u Splitu o, između ostaloga, prihvatljivosti anglizama (odnosno, kako ih autorica naziva, engleskih elemenata) u glagolima i glagolskim imenicima u 
hrvatskim tekstovima o računalima i komunikacijskim tehnologijama. Autorica je upotrijebila upitnik u kojemu su sudionici svoje stavove izražavali na Likertovoj ljestvici od 1 do 5 (gdje je 1 bilo 'potpuno neprihvatljiv', a 5 'potpuno prihvatljiv'). Studentima je bilo ponuđeno devet glagola (npr. resetirati, uploadati, shareati, poskenirati itd.), a najprihvatljivijim su ocijenili resetirati $(4,7)$ a najmanje prihvatljivim outsourceati $(3,0)$. Osim glagola, sudionicima su je bilo ponuđeno i 15 glagolskih imenica (npr. hakiranje, streamanje, taggiranje, svajpanje); najprihvatljivije je hakiranje $(4,8)$ a najneprihvatljivije svajpanje $(2,3)$. Rezultati su pokazali i da sudionici koji češće čitaju tekstove na engleskome jeziku na internetu imaju „statistički značajno veću prosječnu ocjenu prihvatljivosti engleskog elementa" (Matić 2015: 75). Autorica zaključuje da su engleski elementi sudionicima prihvatljivi i razumljivi, ali da se ta prihvatljivost, zanimljivo, smanjuje $s$ prilagođenošću elementa - što je element prilagođeniji hrvatskome jeziku, to je sudionicima bio manje prihvatljiv.

Slično prethodnomu istraživanju, Matić (2017) je ispitala stavove o anglizmima među 54 studenta pete godine Informacijskih i komunikacijskih tehnologija u Splitu; za razliku od prethodnoga, u ovome je istraživanju autorica ispitala i stavove prema hrvatskim zamjenama za nazivlje iz polja studija, ali ne na temelju pojedinačnih riječi već izjava, npr. „Hrvatski naziv ne opisuje koncept precizno" (Matić 2017: 337, autorov prijevod). Sudionici su svoje stavove iskazivali na Likertovoj ljestvici od 1 do 5 (gdje je 1 označivalo 'potpuno neprihvatljivo', a 5 'potpuno prihvatljivo'). Između ostaloga, sudionicima je bilo ponuđeno 13 anglizama (izvori su bili sveučilišni udžbenici i nastavni materijali), a uz neke od njih i neprilagođene inačice, poput rutiranje i routing, videostreaming te firmver i firmwear. Autorica na temelju rezultata zaključuje da sudionici anglizme uglavnom smatraju prihvatljivima, bez obzira na stupanj prilagodbe, i zapravo ih ne doživljavaju stranim elementima te da nisu u potpunosti odbacili hrvatske zamjene $\mathrm{i}$ ne isključuju potencijal hrvatskoga jezika u oblikovanju nazivoslovlja.

U ovome se potpoglavlju nakon četiriju istraživanja stavova valja osvrnuti na još jedan rad čiji cilj nije bio ispitati stavove, ali govori o mogućim razlozima posuđivanja, što je svakako relevantno za naše istraživanje. Drljača Margić (2011) navodi četrnaest razloga posuđivanja i uporabe posuđenica engleskoga porijekla. Primarnom svrhom smatra popunjavanje leksičke praznine te navodi da posuđeni izrazi „i nakon pronalaska domaćih zamjena često ostaju u uporabi zato što ih govornici doživljavaju bliskima, 
preciznima i jasnima i zato što se ponekad samo od stranih izraza izvode nazivi za srodne pojmove" (58). Drugi razlog proširenosti anglizama jest ono što autorica naziva "osmozom” a riječ je o izloženosti engleskome jeziku putem medija. Potom, anglizmi se upotrebljavaju zbog ekonomičnosti jer jednosložna riječ iz engleskoga „spretnija je praktičnija te zvučnija i pamtljivija od odgovarajuće višesložne zamjene ili višerječnoga izraza u drugome jeziku" (59). Četvrti je razlog uporabe riječi iz engleskoga jezika taj što one imaju određenu privlačnost: „asociraju na globalno, moderno, razvijeno i inovativno" (59). Čak i kada anglizam ima odgovarajuću prijevodnu istovrijednicu, govornici taj prijevod smatraju smiješnim. Autorica navodi primjer cash and carry i plati pa nosi, a negativne stavove govornika prema prevedenici objašnjava, između ostaloga, time da je prijevodom došlo do demistifikacije egzotike. Sljedeći je razlog povezan s prethodnim, a odnosi se na prestiž engleskoga jezika - uporabom anglizama, govornici žele pokazati da su „moderni, napredni, naputovani, načitani, obrazovani u svakome pa i jezičnome smislu, dobro informirani i u toku, sofisticirani, cool i u trendu" (61). Kao sljedeći razlog Drljača Margić navodi neutralnost engleskih riječi i izraza budući da ne nemaju emocionalne konotacije kao domaće riječi i izrazi. Jedan od razloga uporabe anglizama svakako je preciznost izričaja, posebice kada je u pitanju nazivlje iz svijeta računala downloadirati je preciznije, jednoznačnije od preuzeti. Slično tome razlogu, anglizmi katkad, tvrdi autorica, daju potpuniji opis te navodi primjer riječi cool umjesto zabavan, super, dobar itd. Nadalje, anglizmi imaju i različiti kolokacijski potencijal u usporedbi s prevedenicama, pa Drljača Margić i to navodi kao razlog. Nimalo nevažan razlog posuđivanja riječi iz engleskoga jezika jest i njihov međunarodni status u raznim područjima: znanosti, oglašavanju i drugima. Važnim razlogom autorica smatra i potrebu izražavanja identiteta, što do izražaja ponajviše dolazi među mladima kao najvećim konzumentima američke popularne kulture. Usto, anglizmi se ne koriste samo za zadovoljavanje društvene funkcije jezika kao u prethodnome razlogu, već i u svrhu ostvarenja simboličke funkcije. Naime, riječi imaju moć da iskažu stav, ideologiju, potrebu ili pak uvjerenje. Pretposljednji razlog koji navodi autorica jest želja za stvaranjem stranoga ozračja, a posljednji jest uporaba anglizama kao sredstva u igrama riječima. Navedene je razloge zanimljivo usporediti s onima koje smo zabilježili u našemu istraživanju. 


\subsection{Odabir anglizama i prevedenica}

S obzirom na to da nismo znali kakvoga će obrazovanja i kojega zanimanja biti naši sudionici, petnaest je anglizama odabrano s pretpostavkom da će biti poznati hrvatskim govornicima različitih profila. U svakome slučaju, sudionici su, zbog prirode konstrukcije zadatka u upitniku, uz anglizam imali i prevedenicu, što je moglo olakšati razumijevanje ako nisu prethodno bili upoznati s danim anglizmom (uporaba je prevedenica $\mathrm{k}$ tomu oprimjerena u rečenici - više o tomu u 3.3. Instrument).

Ponuđeni su anglizmi zastupljeni u jezičnim savjetnicima 555 jezičnih savjeta (Blagus Bartolec i dr. 2016, kratica PJS) i „Bolje je hrvatski!” (kratica BJH), mrežne stranice Instituta za hrvatski jezik i jezikoslovlje koja daje zamjene za česte anglizme u hrvatskome jeziku. Prisutnost se danih riječi u jezičnim savjetnicima također može protumačiti kao dokaz raširene uporabe tih anglizma.

Pored navedenih jezičnih savjetnika, za identificiranje su preporučenih zamjena upotrijebljeni i sljedeći izvori: članak „Novotvorenice u računalnome nazivlju" (Halonja i Mihaljević 2012) i knjige Jezik medija (Hudeček i Mihaljević 2009), Hrvatski ni u zagradama (Opačić 2012) i Reci mi to kratko i jasno (Opačić 2015). Potvrde prevedenica tražene su i u dvama rječnicima: Školskome rječniku hrvatskoga jezika (Hudeček i Mihaljević 2012, kratica ŠRH) i Velikome rječniku hrvatskoga standardnog jezika (Jojić 2015, kratica VRH).

U tablici 1 dan je prikaz petnaest anglizama i prevedenica ponuđenih $\mathrm{u}$ istraživanju; $\mathrm{u}$ trećemu je stupcu navedena preporučena prevedenica $\mathrm{i}$ izvor preporuke. Brojke ispod ponuđenih anglizama i prevedenica označavaju broj pojavnica anglizama i prevedenica u Hrvatskome mrežnom korpusu ${ }^{1}$. Gdjegdje je u prvome stupcu navedena riječ u zagradi i pripadajući broj pojavnica - riječ je o alternativnome pisanju danoga anglizma, a koje nije bilo ponuđeno u istraživanju ali je relevantno zbog sagledavanja čestote.

1 http://nlp.ffzg.hr/resources/corpora/hrwac/ (pristupljeno 26. lipnja 2019.) 
Tablica 1. Pregled anglizama i prevedenica ponuđenih u istraživanju s pripadajućim brojem pojavnica u Hrvatskome mrežnom korpusu te preporučenim prevedenicama i izvorima tih preporuka

\begin{tabular}{|c|c|c|}
\hline $\begin{array}{l}\text { Ponuđeni } \\
\text { anglizam }\end{array}$ & $\begin{array}{l}\text { Ponuđena } \\
\text { prevedenica }\end{array}$ & $\begin{array}{l}\text { Preporučena } \\
\text { prevedenica }\end{array}$ \\
\hline $\begin{array}{l}\text { apdejatati, } \\
\text { updateati } \\
130,327 \\
\text { (updejtati 215) }\end{array}$ & $\begin{array}{l}\text { posuvremeniti } \\
1 \text { (u traženome } \\
\text { značenju) }\end{array}$ & $\begin{array}{l}\text { posuvremeniti, posuvremenjivati } \\
\text { PJS, BJH, ŠRH, VRH (u rječnicima se } \\
\text { stavlja u sinoniman odnos s ažurirati) }\end{array}$ \\
\hline $\begin{array}{l}\text { attachment } \\
1031 \\
\text { (atačment 33) }\end{array}$ & $\begin{array}{l}\text { privitak } \\
*\end{array}$ & $\begin{array}{l}\text { privitak } \\
\text { PJS, BJH, ŠRH, VRH } \\
\text { prilog } \\
\text { Opačić 2012, } 2015\end{array}$ \\
\hline $\begin{array}{l}\text { blog } \\
118355\end{array}$ & $\begin{array}{l}\text { internetski } \\
\text { dnevnik } \\
127 \text { (ne odnosi } \\
\text { se samo na blog) }\end{array}$ & $\begin{array}{l}\text { mrežni/internetski dnevnik } \\
\text { PJS, BJH } \\
\text { mrežni dnevnik } \\
\text { ŠRH, VRH } \\
\text { internetski dnevnik } \\
\text { Hudeček i Mihaljević } 2009\end{array}$ \\
\hline $\begin{array}{l}\text { brainstorming } \\
588\end{array}$ & $\begin{array}{l}\text { razmjena ideja } \\
*\end{array}$ & $\begin{array}{l}\text { razmjena ideja/mišljenja } \\
\text { PJS, BJH } \\
\text { razmjena mišljenja } \\
\text { Hudeček i Mihaljević } 2009\end{array}$ \\
\hline $\begin{array}{l}\text { downloadati, } \\
\text { downloadirati } \\
3181,427\end{array}$ & $\begin{array}{l}\text { preuzeti } \\
*\end{array}$ & $\begin{array}{l}\text { preuzeti } \\
\text { PJS, BJH } \\
\text { Hudeček i Mihaljević } 2009 \\
\end{array}$ \\
\hline $\begin{array}{l}e-m a i l \\
46055\end{array}$ & $\begin{array}{l}\text { e-pošta } \\
3166\end{array}$ & $\begin{array}{l}\text { e-pošta, e-poruka, e-adresa } \\
\text { PJS, BJH, ŠRH, VRH } \\
\text { elektronička pošta, elektronička poruka } \\
\text { Hudeček i Mihaljević } 2009\end{array}$ \\
\hline $\begin{array}{l}\text { isprintati } \\
2588\end{array}$ & $\begin{array}{l}\text { ispisati } \\
*\end{array}$ & $\begin{array}{l}\text { ispisati } \\
\text { BJH, ŠRH, VRH (rječnici ne donose traženu } \\
\text { definiciju kod glagola ispisati, ali definiraju } \\
\text { ispis kao 'tekst otisnut na papiru' odnosno } \\
\text { 'sadržaj koje datoteke ispisan na papiru s } \\
\text { pomoću pisača') }\end{array}$ \\
\hline $\begin{array}{l}\text { link } \\
86246\end{array}$ & $\begin{array}{l}\text { poveznica } \\
*\end{array}$ & $\begin{array}{l}\text { poveznica } \\
\text { PJS, BJH, ŠRH, VRH }\end{array}$ \\
\hline
\end{tabular}




\begin{tabular}{|c|c|c|}
\hline $\begin{array}{l}\text { Ponuđeni } \\
\text { anglizam }\end{array}$ & $\begin{array}{l}\text { Ponuđena } \\
\text { prevedenica }\end{array}$ & $\begin{array}{l}\text { Preporučena } \\
\text { prevedenica }\end{array}$ \\
\hline $\begin{array}{l}\text { mobbing } \\
2657 \\
(\text { mobing 1956) }\end{array}$ & $\begin{array}{l}\text { zlostavljanje na } \\
\text { poslu } \\
126 \text { (ne odnosi } \\
\text { se samo na } \\
\text { mobbing) }\end{array}$ & $\begin{array}{l}\text { zlostavljanje na poslu, na radnome mjestu } \\
\text { PJS, BJH, VRH (rječnik definira mobing kao } \\
\text { 'emotivno zlostavljanje na radnom mjestu') } \\
\text { zlostavljanje na radnome mjestu } \\
\text { Hudeček i Mihaljević } 2009\end{array}$ \\
\hline $\begin{array}{l}\text { multitasking } \\
1324\end{array}$ & $\begin{array}{l}\text { višezadaćnost } \\
70\end{array}$ & $\begin{array}{l}\text { višezadaćnost } \\
\text { PJS, BJH }\end{array}$ \\
\hline $\begin{array}{l}\text { slajd, slide } \\
2030,2266\end{array}$ & $\begin{array}{l}\text { slikokaz } \\
78 \text { (ne odnosi se } \\
\text { samo na slide) }\end{array}$ & $\begin{array}{l}\text { kliznica } \\
\text { Halonja i Mihaljević } 2012 \\
\text { sličica } \\
\text { PJS, BJH } \\
\text { slikokaz } \\
\text { VRH }\end{array}$ \\
\hline $\begin{array}{l}\text { shopping } \\
14080 \\
\text { (šoping 9995) }\end{array}$ & $\begin{array}{l}\text { kupnja, kupovina } \\
\text { * }\end{array}$ & $\begin{array}{l}\text { kupovanje, kupnja } \\
\text { BJH, ŠRH, VRH }\end{array}$ \\
\hline $\begin{array}{l}\text { viralni video } \\
65\end{array}$ & $\begin{array}{l}\text { virusni video } \\
4\end{array}$ & $\begin{array}{l}\text { virusni (marketing) } \\
\text { PJS }\end{array}$ \\
\hline $\begin{array}{l}\text { webinar } \\
688\end{array}$ & $\begin{array}{l}\text { mrežni seminar } \\
0\end{array}$ & $\begin{array}{l}\text { mrežni seminar } \\
\text { PJS, BJH }\end{array}$ \\
\hline $\begin{array}{l}\text { web-stranica } \\
6916\end{array}$ & $\begin{array}{l}\text { mrežna stranica } \\
157\end{array}$ & $\begin{array}{l}\text { mrežna stranica } \\
\text { PJS, BJH, ŠRH (u rječniku kao primjer za } \\
\text { pridjev mrežni) }\end{array}$ \\
\hline
\end{tabular}

* Nije naveden broj pojavnica zbog višeznačnosti prevedenice.

\section{Metodologija}

\subsection{Ciljevi i istraživačka pitanja}

Cilj je istraživanja bio ispitati stavove govornika hrvatskoga jezika spram anglizama i pripadajućih prevedenica. U ostvarivanju cilja vodili smo se sljedećim istraživačkim pitanjima:

1. Postoji li razlika među sudionicima s obzirom na spol, dob, stupanj obrazovanja, zanimanje, znanje engleskoga jezika, broja stranih jezika a u vidu povezanosti tih varijabli s jezičnom kulturom sudionika i njihovom vjerojatnošću uporabe prevedenice? 
2. Koje su od ponuđenih prevedenica najmanje, a koje najviše prihvatljive?

3. Može li se prevedenice kategorizirati prema stupnju prihvatljivosti?

4. Koji su razlozi zašto sudionici radije biraju anglizme odnosno prevedenice?

\subsection{Provedba istraživanja}

Podatci su prikupljani krajem veljače 2019., a kvantitativna je i kvalitativna analiza provedena od ožujka do srpnja 2019. godine. Kvantitativni su podatci obrađeni u programu Statistica.

\subsection{Instrument}

Za prikupljanje odgovora sudionika upotrijebljen je mrežni upitnik koji se sastojao od četiriju dijelova. Prvi je dio sadržavao privolu za prikupljanje i obradu podataka pod određenim uvjetima. Ovisno o davanju ili uskraćivanju privole, sudionici su nastavili na drugi dio upitnika ili završili sudjelovanje $u$ istraživanju. $U$ drugome su se dijelu od sudionika tražile opće informacije (spol, dob, razina obrazovanja, zanimanje, poznavanje stranih jezika), a u trećemu su sudionici na ljestvici od 1 do 5 označivali koliko je vjerojatno da bi upotrijebili određenu hrvatsku inačicu za riječ iz engleskoga jezika u pisanoj formalnoj komunikaciji, gdje je 1 označivalo 'nije vjerojatno', a 5 'vrlo vjerojatno'. Bilo je ponuđeno petnaest parova riječi. U upitniku je pojašnjeno što se smatra pisanom formalnom komunikacijom („Formalnom pisanom komunikacijom smatra se službena pisana komunikacija u vidu emailova, dopisa, zahtjeva, molbi, pritužbi, prezentacija i sl."), a uz svaki je par riječi dan primjer hrvatske riječi u kontekstu, primjerice, za par e-pošta - e-mail dana je rečenica „Rezultate ćemo poslati e-poštom”. U posljednjemu se dijelu od sudionika tražilo da objasne svoje stavove pisanim odgovorima, da na ljestvici od 1 do 5 izraze svoje slaganje odnosno neslaganje s određenim tvrdnjama te da odgovore i na dva pitanja vezana uz praćenje jezičnih savjeta.

\subsection{Uzorak}

Upitniku je pristupio 1381 sudionik, od kojih 41 nije dao privolu za sudjelovanje $\mathrm{u}$ istraživanju te je stoga konačan uzorak činilo 1340 sudionika. Većinu sudionika činile su žene (89 \%). Na slici 1 vidljivo je da je najviše sudionika $(69,8 \%)$ bilo u dobi od 31 do 50 godina, nakon čega slijede oni u dobi od 21 do 30 godina (17,8\%). 


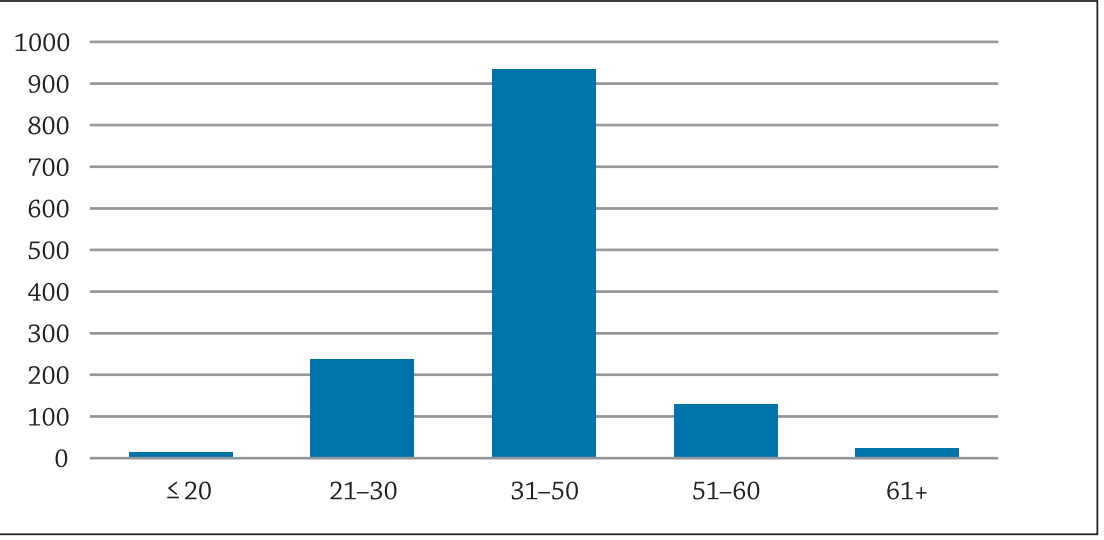

Slika 1. Dob sudionika

Najčešće su sudionici (78.4 \%) imali fakultetsko obrazovanje od četiri odnosno pet godina (slika 2).

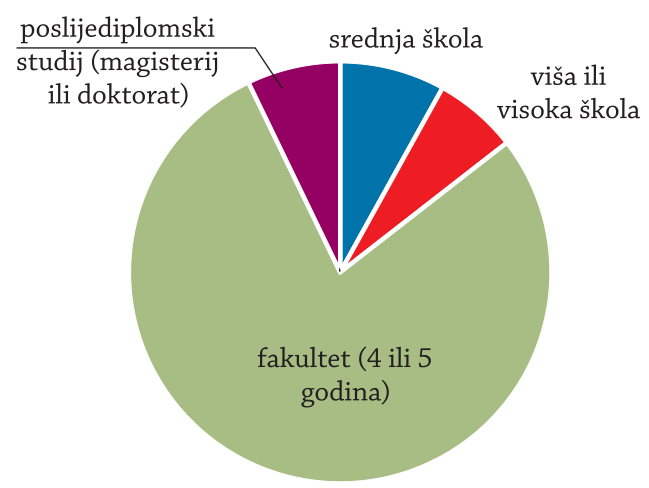

Slika 2. Razina obrazovanja sudionika

Kada je riječ o zanimanju, 75,1 \% sudionika radi u odgojno-obrazovnim ustanovama; riječ je o odgojiteljima, učiteljima, nastavnicima, ravnateljima, stručnim suradnicima, a koji čine jedinstvenu kategoriju s obzirom na to da se u Hrvatskoj, a prema Zakonu o odgoju i obrazovanju u osnovnoj i srednjoj školi, nastava izvodi na hrvatskome jeziku. Tablica 2 donosi prikaz zanimanja sudionika. Sljedeću kategoriju po brojnosti, 11,6 \% sudionika, 
čine osobe koje obavljaju poslove u kojima jezik nije primaran interes, poput ekonomista, umjetnika, zdravstvenih radnika i sl. Iako i službenici, pravnici i prevoditelji trebaju, pretpostavljamo, voditi računa o hrvatskome jeziku jednako kao i novinari i urednici, ove su dvije kategorije razdvojene jer sudionici istraživanja često navode da anglizmi do njih dolaze putem medija. Prvu skupinu čini 66 sudionika, dok drugu, najmanju, tek 22. Između tih skupina nalazi se 49 sudionika informatičara ili inženjera za koje pretpostavljamo da u poslu upotrebljavaju englesko nazivlje te 41 sudionik koji nije zaposlen, a tu se ubrajaju i umirovljenici i studenti.

Tablica 2. Zanimanje sudionika

\begin{tabular}{|l|c|c|}
\hline \multicolumn{1}{|c|}{ Zanimanje } & Broj sudionika & Postotak \\
\hline Odgojno-obrazovni radnik & 1006 & 75,1 \\
\hline $\begin{array}{l}\text { Radnik zanimanja u kojemu jezik nije primaran } \\
\text { interes }\end{array}$ & 156 & 11,6 \\
\hline Službenik, pravnik, prevoditelj & 66 & 4,9 \\
\hline Informatičar, inženjer & 49 & 3,7 \\
\hline Nezaposlen & 41 & 3,1 \\
\hline Novinar, urednik & 22 & 1,6 \\
\hline Ukupno & 1340 & 100 \\
\hline
\end{tabular}

Engleski jezik govori 94,9 \% sudionika. Na slici 3 može se vidjeti da je najviše onih koji govore dva strana jezika $(36,6 \%)$ a potom onih koji govore jedan strani jezik (36,4 \%).

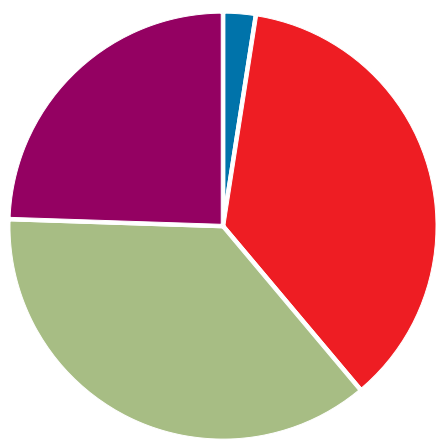

घ ne govori strani jezik $\square$ jedan $\square$ dva $\quad$ tri i više

Slika 3. Broj stranih jezika sudionika 
Slika 4 daje podatke o stranim jezicima sudionika te se kao najčešći ističu njemački jezik (33,7 \%) i talijanski jezik (29,0 \%). Pored navedenih jezika, tek nekoliko sudionika govori i druge jezike: češki, poljski, švedski, mađarski itd.

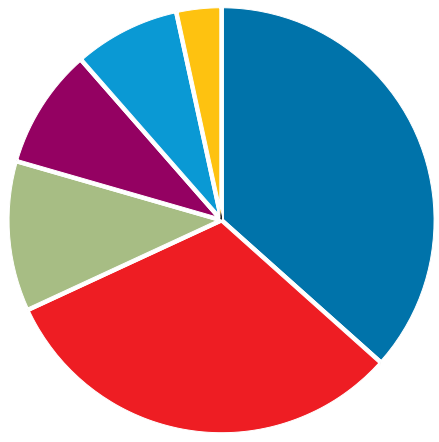

njemački $\square$ talijanski $\square$ španjolski $\square$ slovenski $\square$ francuski $\square$ ruski

Slika 4. Strani jezici sudionika

$\mathrm{Na}$ temelju opisanoga uzorka, jasno je da riječ o prigodnome uzorku koji je pristran s obzirom na spol te obrazovanje i zanimanje sudionika, pa navedeno treba uzeti u obzir kao ograničenje ovoga istraživanja.

\section{Rezultati}

\subsection{Kvantitativna analiza}

Kako bismo odgovorili na prvo istraživačko pitanje, u kvantitativnoj smo analizi ispitali moguću povezanost varijabli spola, dobi, obrazovanja, zanimanja, znanja engleskoga jezika, broja stranih jezika te dvaju koeficijenata koji su osmišljeni u svrhu ovoga istraživanja. Koeficijent jezične kulture (KJK) temelji se na odgovorima sudionika o tome što misle o korisnosti jezičnih savjeta stručnjaka i prestižu engleskoga spram hrvatskoga jezika te prate li i koliko često emisije o hrvatskome standardnom jeziku. KJK stoga pokazuje zanimanje za hrvatski (standardni) jezik, a viši rezultat upućuje na višu razinu jezične kulture kako je shvaćena u ovome radu. KJK je važan sa stajališta opće procjene sudionika istraživanja. Koeficijent (vjerojatnosti) uporabe prevedenice (KUP) proizlazi iz prosjeka odgovora sudionika na vjerojatnost uporabe petnaest ponuđenih prevede- 
nica. Viši koeficijent znači da je sudionik skloniji uporabi hrvatskih zamjena za anglizme.

Kvantitativna je analiza rađena u programu Statistica, a provedeni su t-testovi i analize varijance. U slučaju utvrđivanja statistički značajne razlike $\mathrm{u}$ analizi varijance, napravljen je LSD post-hoc test kako bi se ispitalo koja od podskupina pridonosi danoj statistički značajnoj razlici $(\mathrm{p}<, 05)$. Statistički je značajan rezultat u tablicama koje slijede osjenčan. Druge ključne vrijednosti istaknute su masnim tiskom.

$\mathrm{Na}$ samome početku kvantitativne analize valja naglasiti da je pronađena statistički značajna pozitivna povezanost srednje snage između KJK-a i KUP-a $(r=, 4179, p<, 01)$, što znači da su sudionici istraživanja $s$ višom razinom jezične kulture pokazali spremnijima upotrijebiti prevedenicu te obratno - oni s nižim KJK-om pokazali su se manje sklonima koristiti prevedenice.

U pogledu spola, analiza je pokazala da muškarci imaju statistički značajno niži KJK i KUP, što je razvidno iz tablice 3.

Tablica 3. Razlika u dvama koeficijentima između žena i muškaraca

\begin{tabular}{|l|c|c|c|c|c|c|}
\hline & žene & muškarci & $\mathbf{d f}$ & $\mathbf{p}$ & SD žene & SD muškarci \\
\hline KJK & $\mathbf{3 , 4 4}$ & $\mathbf{3 , 0 8}$ & 1338 & 0,000000 & 0,82 & 0,86 \\
\hline KUP & $\mathbf{2 , 7 6}$ & $\mathbf{2 , 5 8}$ & 1338 & 0,010008 & 0,76 & 0,75 \\
\hline
\end{tabular}

S obzirom na dob sudionika, utvrđeno je da KJK i KUP rastu s dobi, no taj je rast statistički značajan samo u odnosu na određene skupine, što je razvidno iz tablice 4 i tablice 5. Prosječni KJK najmlađih sudionika iznosi 2,45, a najstarijih 3,84 , dok je prosječni KUP najmlađih 2,10, a najstarijih 3,14.

Tablica 4. Koeficijent jezične kulture s obzirom na dob

\begin{tabular}{|l|c|c|c|c|c|}
\hline & $\leq 20$ & $21-30$ & $31-50$ & $51-60$ & $61+$ \\
& $\mathbf{M}=2,45$ & $\mathbf{M}=3,31$ & $\mathbf{M}=3,42$ & $\mathbf{M}=3,50$ & $\mathbf{M}=3,84$ \\
& $\mathrm{SD}=0,82$ & $\mathrm{SD}=0,87$ & $\mathrm{SD}=0,80$ & $\mathrm{SD}=0,83$ & $\mathrm{SD}=0,86$ \\
\hline$\leq 20$ & & 0,000155 & 0,000014 & 0,000006 & 0,000001 \\
\hline $21-30$ & 0,000155 & & 0,071979 & 0,029868 & 0,002996 \\
\hline $31-50$ & 0,000014 & 0,071979 & & 0,255962 & 0,014138 \\
\hline $51-60$ & 0,000006 & 0,029868 & 0,255962 & & 0,068648 \\
\hline $61+$ & 0,000001 & 0,002996 & 0,014138 & 0,068648 & \\
\hline
\end{tabular}


Tablica 5. Koeficijent (vjerojatnosti) uporabe prevedenice s obzirom na dob

\begin{tabular}{|l|c|c|c|c|c|}
\hline \multirow{2}{*}{ Dob } & $\leq 20$ & $21-30$ & $31-50$ & $51-60$ & $61+$ \\
& $\mathbf{M}=2,10$ & $\mathbf{M}=2,70$ & $\mathbf{M}=2,71$ & $\mathbf{M}=2,97$ & $\mathbf{M}=3,14$ \\
& $\mathrm{SD}=0,49$ & $\mathrm{SD}=0,72$ & $\mathrm{SD}=0,74$ & $\mathrm{SD}=0,90$ & $\mathrm{SD}=0,91$ \\
\hline$\leq 20$ & & 0,003682 & 0,002468 & 0,000044 & 0,000047 \\
\hline $21-30$ & 0,003682 & & 0,819675 & 0,001241 & 0,007559 \\
\hline $31-50$ & 0,002468 & 0,819675 & & 0,000338 & 0,007250 \\
\hline $51-60$ & 0,000044 & 0,001241 & 0,000338 & & 0,306902 \\
\hline $61+$ & 0,000047 & 0,007559 & 0,007250 & 0,306902 & \\
\hline
\end{tabular}

Nadalje, oba koeficijenta rastu do treće razine obrazovanja (4 ili 5 godina fakulteta), a potom opadaju; no, statistički je značajna razlika samo između najniže obrazovanih i ostalih, što je vidljivo u tablici 6 i tablici 7 . Najviši KJK i KUP imaju oni s četverogodišnjim odnosno petogodišnjim fakultetskim obrazovanjem, KJK 3,46 i KUP 2,78, a najniži sudionici sa završenom srednjom školom, odnosno KJK 2,96 i KUP 2,40.

Tablica 6. Koeficijent jezične kulture s obzirom na obrazovanje

\begin{tabular}{|c|c|c|c|c|}
\hline Razina obrazovanja & $\begin{array}{c}\begin{array}{c}\text { Srednja } \\
\text { škola }\end{array} \\
\mathbf{M}=2,96 \\
\mathrm{SD}=0,79\end{array}$ & $\begin{array}{c}\text { Viša ili } \\
\text { visoka škola } \\
\mathbf{M}=3,29 \\
\mathrm{SD}=0,90\end{array}$ & $\begin{array}{l}\text { Fakultet } \\
\mathbf{M}=3,46 \\
\mathrm{SD}=0,82\end{array}$ & $\begin{array}{c}\text { Poslije- } \\
\text { diplomski } \\
\text { studij } \\
\mathbf{M}=3,41 \\
\text { SD }=0,77\end{array}$ \\
\hline Srednja škola & & 0,005630 & 0,000000 & 0,000117 \\
\hline Viša ili visoka škola & 0,005630 & & 0,071953 & 0,341417 \\
\hline Fakultet & 0,000000 & 0,071953 & & 0,569377 \\
\hline Poslijediplomski studij & 0,000117 & 0,341417 & 0,569377 & \\
\hline
\end{tabular}


Tablica 7. Koeficijent (vjerojatnosti) uporabe prevedenice s obzirom na obrazovanje

\begin{tabular}{|l|c|c|c|c|}
\hline Razina obrazovanja & $\begin{array}{c}\text { Srednja } \\
\text { škola } \\
\mathbf{M}=2,40 \\
\mathrm{SD}=0,73\end{array}$ & $\begin{array}{c}\text { Viša ili } \\
\text { visoka škola } \\
\mathbf{M}=2,67 \\
\mathrm{SD}=0,95\end{array}$ & $\begin{array}{c}\text { Fakultet } \\
\mathbf{M}=2,78\end{array}$ & $\begin{array}{c}\text { Poslije- } \\
\text { diplomski } \\
\text { studij } \\
\mathbf{M}=\mathbf{0 , 7 5}\end{array}$ \\
\hline Srednja škola & & 0,015196 & 0,000001 & 0,003453 \\
\hline Viša ili visoka škola & 0,015196 & & 0,187790 & 0,688154 \\
\hline Fakultet & 0,000001 & 0,187790 & & 0,408252 \\
\hline Poslijediplomski studij & 0,003453 & 0,688154 & 0,408252 & \\
\hline
\end{tabular}

U pogledu zanimanja sudionika, najviši KJK imaju novinari i urednici $(3,58)$ te odgojno-obrazovni radnici $(3,50)$, dok je najniži zabilježen kod nezaposlenih (2,93). Kada je riječ o KUP-u, najviši koeficijent imaju odgojno-obrazovni radnici $(2,82)$, dok najniži imaju radnici zanimanja u kojima jezik nije primaran interes $(2,31)$. Statistički značajne razlike između skupina prikazane su u tablici 8 i tablici 9 .

Tablica 8. Koeficijent jezične kulture s obzirom na zanimanje

\begin{tabular}{|c|c|c|c|c|c|c|}
\hline Zanimanje & $\begin{array}{c}1 \\
\mathbf{M}=3,50 \\
S D=0,81\end{array}$ & $\begin{array}{c}2 \\
\mathbf{M}=\mathbf{3 , 0 7} \\
\mathrm{SD}=0,77\end{array}$ & $\begin{array}{c}3 \\
\mathbf{M}=3,23 \\
\mathrm{SD}=0,80\end{array}$ & $\begin{array}{c}4 \\
\mathbf{M}=3,04 \\
\mathrm{SD}=0,95\end{array}$ & $\begin{array}{c}5 \\
M=2,93 \\
S D=0,86 \\
\end{array}$ & $\begin{array}{c}6 \\
M=3,58 \\
S D=0,68\end{array}$ \\
\hline $\begin{array}{l}\text { Odgojno- } \\
\text { obrazovni } \\
\text { radnik }\end{array}$ & & 0,000000 & 0,008374 & 0,000393 & 0,000001 & 0,658445 \\
\hline $\begin{array}{l}\text { Radnik - jezik } \\
\text { nije primaran } \\
\text { interes }\end{array}$ & 0,000000 & & 0,193214 & 0,821697 & 0,265769 & 0,006396 \\
\hline $\begin{array}{l}\text { Službenik, } \\
\text { pravnik, } \\
\text { prevoditelj }\end{array}$ & 0,008374 & 0,193214 & & 0,246164 & 0,047848 & 0,080352 \\
\hline $\begin{array}{l}\text { Informatičar, } \\
\text { inženjer }\end{array}$ & 0,000393 & 0,821697 & 0,246164 & & 0,500108 & 0,012429 \\
\hline Nezaposlen & 0,000001 & 0,265769 & 0,047848 & 0,500108 & & 0,001762 \\
\hline $\begin{array}{l}\text { Novinar, } \\
\text { urednik }\end{array}$ & 0,658445 & 0,006396 & 0,080352 & 0,012429 & 0,001762 & \\
\hline
\end{tabular}


Tablica 9. Koeficijent (vjerojatnosti) uporabe prevedenice s obzirom na zanimanje

\begin{tabular}{|l|c|c|c|c|c|c|}
\hline \multicolumn{1}{|c|}{ Zanimanje } & $\begin{array}{c}1 \\
\mathbf{M}=2,82 \\
\mathrm{SD}=0,76\end{array}$ & $\begin{array}{c}\mathbf{M}=2,31 \\
\mathrm{SD}=0,64\end{array}$ & $\begin{array}{c}3 \\
\mathbf{M}=2,62 \\
\mathrm{SD}=0,69\end{array}$ & $\begin{array}{c}4 \\
\mathbf{M}=2,66 \\
\mathrm{SD}=0,81\end{array}$ & $\begin{array}{c}5 \\
\mathbf{M}=2,64 \\
\mathrm{SD}=0,76\end{array}$ & $\begin{array}{c}\mathbf{M}=2,44 \\
\mathrm{SD}=0,77\end{array}$ \\
\hline $\begin{array}{l}\text { Odgojno- } \\
\text { obrazovni } \\
\text { radnik }\end{array}$ & 0,000000 & 0,028260 & 0,163354 & 0,083641 & 0,016761 \\
\hline $\begin{array}{l}\text { Radnik - jezik } \\
\text { nije primaran } \\
\text { interes }\end{array}$ & 0,000000 & 0,005734 & 0,008410 & 0,008424 & 0,457613 \\
\hline $\begin{array}{l}\text { Službenik, } \\
\text { pravnik, } \\
\text { prevoditelj }\end{array}$ & 0,028260 & 0,005734 & & 0,775040 & 0,891316 & 0,335645 \\
\hline $\begin{array}{l}\text { Informatičar, } \\
\text { inženjer }\end{array}$ & 0,163354 & 0,008410 & 0,775040 & & 0,883318 & 0,266222 \\
\hline Nezaposlen & 0,083641 & 0,008424 & 0,891316 & 0,883318 & & 0,305861 \\
\hline $\begin{array}{l}\text { Novinar, } \\
\text { urednik }\end{array}$ & 0,016761 & 0,457613 & 0,335645 & 0,266222 & 0,305861 & \\
\hline
\end{tabular}

Kada je u pitanju poznavanje engleskoga jezika, ono nije statistički značajno povezano s KJK-om, ali jest s KUP-om. KUP za one koji znaju engleski jezik iznosi 2,72 (SD=0,76), a za one koji su izjavili da ne znaju engleski jezik 3,04 (SD=0,85). Drugim riječima, sudionici koji su izjavili da ne znaju engleski jezik manje su skloni tvrditi da prevedenicu ne bi upotrijebili.

Što se tiče broja stranih jezika koji sudionici govore, nije pronađena statistička povezanost te varijable sa spomenutim koeficijentima, kao ni s ostalim ispitivanim varijablama.

Kako bismo odgovorili na drugo i treće istraživačko pitanje, analizirali smo odgovore na petnaest ponuđenih prevedenica. Kao što se može vidjeti na slici 5, sudionici su najmanje skloni tomu da uporabe riječi slikokaz i višezadaćnost. Valja istaknuti da te riječi imaju zajednička obilježja - riječ je o kalkovima koji $\mathrm{k}$ tome imaju malen broj pojavnica naspram anglizama $\mathrm{u}$ Hrvatskome mrežnom korpusu, što upućuje na to da nisu česti u uporabi. Dapače, čini se da su toliko rijetki pa jedan sudionik dovodi u pitanje njihovo postojanje: „Neke hrvatske riječi koje ste ponudili doslovno ne postoje i ridikulozne su (višezadaćnost, slikokaz)...”; drugomu sudioniku 
djeluju smiješno te ima „osjećaj kao da [ga] sugovornici ne bi doživjeli ozbiljno”; trećemu pak slikokaz „zvuči kao loša šala s početka devedesetih”.

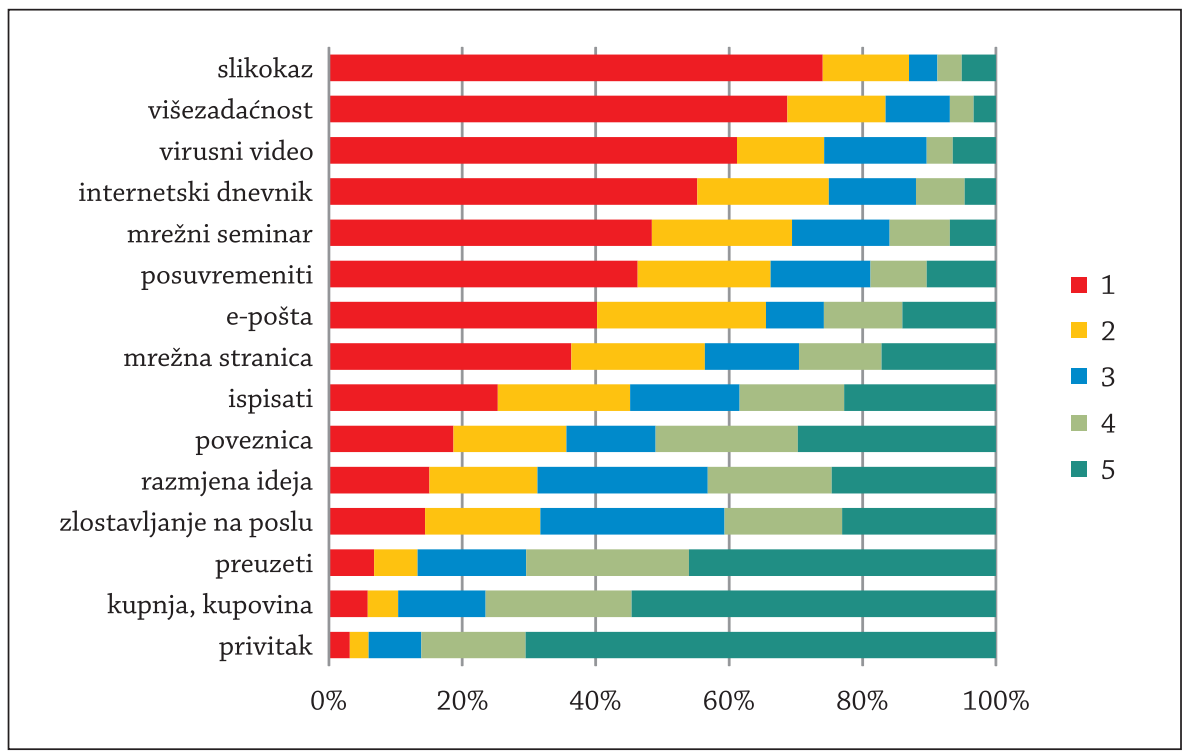

Slika 5. Prikaz vjerojatnosti uporabe odabrane prevedenice, gdje je 1 označivalo 'nije vjerojatno' a 5 'vrlo vjerojatno'.

Mnogi sudionici nisu spremni upotrijebiti ni virusni video, za koji su u svojim pisanim odgovorima objasnili da ne prenosi isto značenje kao viralni video (vidi primjere 19-21 u Kvalitativnoj analizi), a potom ni internetski dnevnik koji se pokazao nedostatnom zamjenom za blog.

$S$ druge strane, većina je sudionika sklona upotrijebiti riječi privitak, kupnja/kupovina i preuzeti umjesto riječi attachment, shopping i downloadati/ downloadirati. Znakovito je da su te tri riječi i otprije postojale u hrvatskome jeziku, samo je njihovo značenje prošireno (vidi primjere 49-52 u Kvalitativnoj analizi). U Diskusiji ćemo stoga ponuditi moguću kategorizaciju prevedenica s obzirom na stupanj prihvatljivosti, a kao odgovor na treće i četvrto istraživačko pitanje.

U nastavku se kvantitativne analize daju prikazi odgovora na nekoliko relevantnih tvrdnji. Tako je iz slike 6 uočljivo da 307 sudionika (22,91 \%) smatra da prevedenice udomaćenih riječi iz engleskoga jezika nisu potrebne. 


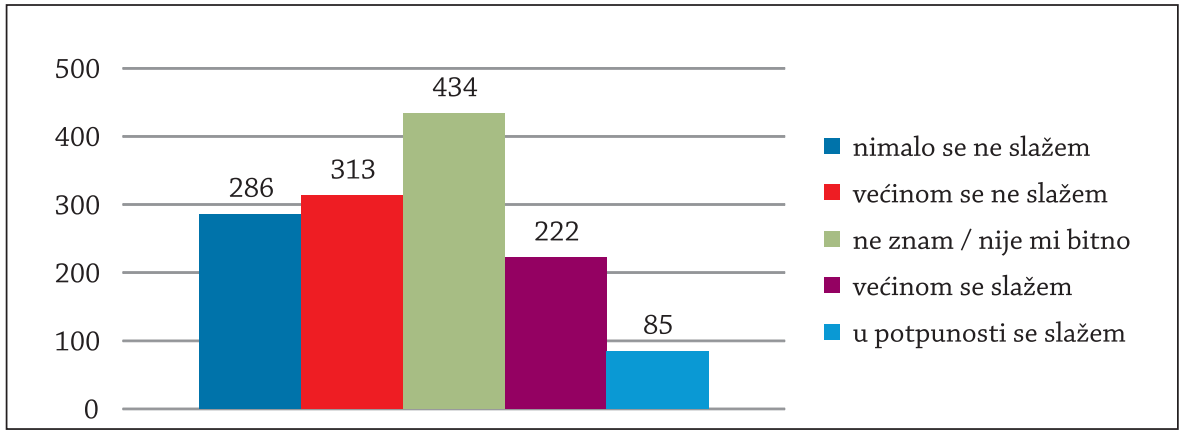

Slika 6. Prikaz odgovora sudionika na tvrdnju da prevedenice udomaćenih riječi iz engleskoga jezika nisu potrebne

Nadalje, unatoč utvrđenim niskim KUP-om i ne odveć visokim KJKom, većina sudionika $(74,48 \%)$ ipak smatra da su jezični savjeti jezikoslovaca i lektora korisni, što se dade vidjeti na slici 7 . K tomu, 80,97 \% sudionika izjavilo je da posjeduje jezični savjetnik (priručnik).

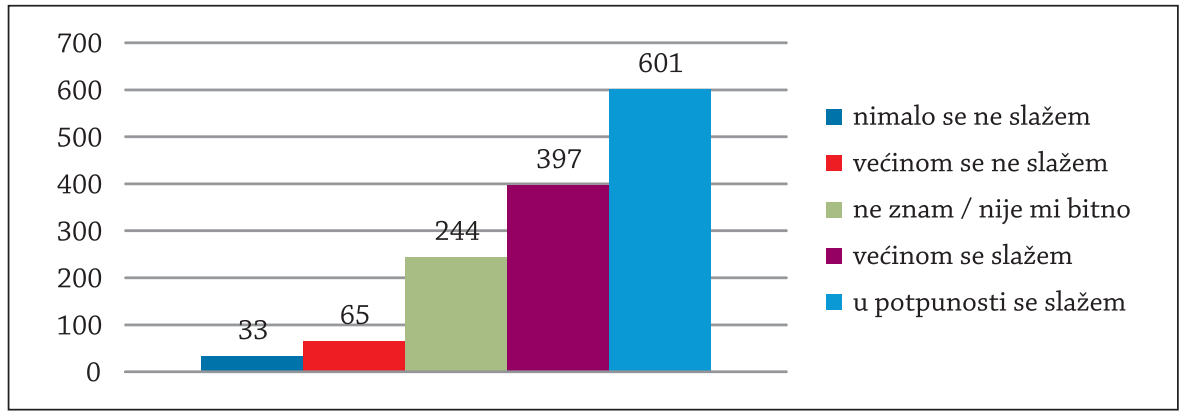

Slika 7. Prikaz odgovora sudionika na tvrdnju da su jezični savjeti jezikoslovaca i lektora korisni

U skladu s prethodnim rezultatom, većina je sudionika (80,67 \%) izjavila da prati emisije na radiju ili televiziji a koje donose savjete o hrvatskome standardnom jeziku, neki rjeđe, a drugi češće, kao što je vidljivo na slici 8. 


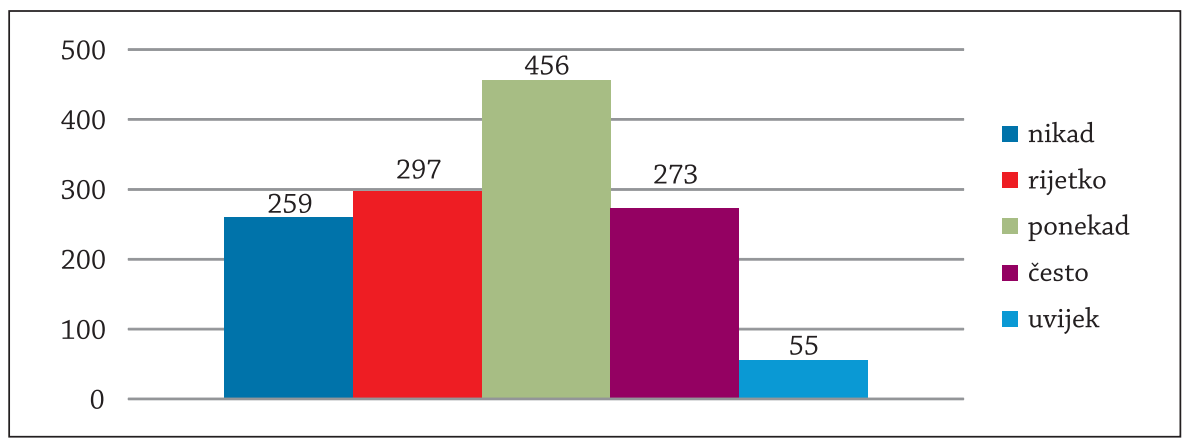

Slika 8. Prikaz odgovora sudionika o učestalosti praćenja emisija sa savjetima o hrvatskome standardnom jeziku

Konačno, kao što se može vidjeti na slici 9 , gotovo polovica sudionika (49,55 \%) engleski jezik ne smatra prestižnijim od hrvatskoga.

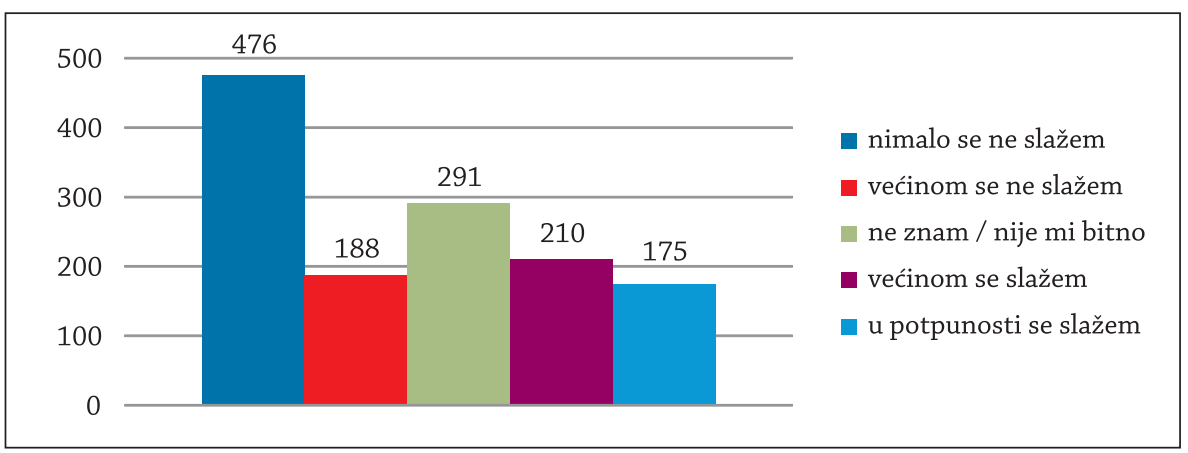

Slika 9. Prikaz odgovora sudionika na tvrdnju da je engleski jezik prestižniji od hrvatskoga

\subsection{Kvalitativna analiza}

Kako bismo odgovorili na četvrto istraživačko pitanje, proveli smo kvalitativnu analiza pisanih odgovora sudionika na dva pitanja. Prvo se pitanje odnosilo na sklonost uporabi anglizama, a drugo na sklonost uporabi prevedenica. Odgovore smo sudionika svrstali u devet kategorija koje obuhvaćaju razloge uporabe anglizama i osam kategorija koje obuhvaćaju razloge uporabe prevedenica. 


\subsubsection{Prihvatljivost anglizama spram hrvatskih zamjena}

$\mathrm{Na}$ česticu „Ako su Vam općenito prihvatljivije riječi koje smo primili iz engleskoga jezika negoli hrvatske inačice, molim Vas ukratko obrazložite zašto." odgovorilo je 526 sudionika, a te smo odgovore svrstali u devet kategorija sa sljedećim nazivima: raširenost uporabe $(177)^{2}$, razumljivost (113), dojam (75), navika (52), neadekvatan prijevod (50), posao (24), izloženost (18), priroda jezika (12) te otpor (5).

Najviše sudionika kao razlog odabira engleske riječi navodi to što su te riječi, za razliku od hrvatskih zamjena, raširenije u uporabi:

(1) Prve mi padnu napamet jer se često koriste.

(2) Zato jer se generalno češće upotrebljavaju nego hrvatske inačice.

(3) Te engleski riječi su sveprisutne i nailazim na njih svakodnevno.

(4) Jer su ove riječi usvojene u hrvatskom jeziku kao da su dio njega.

Dio tih sudionika prepoznaje da su engleske inačice prije ušle u jezik negoli hrvatske i stoga su raširenije:

(5) Ušle su u upotrebu prije hrvatskih inačica pa sam ih prihvatila i zadržala.

(6) Zbog toga što je takva riječ korištena prije nego što sam znao koji je prihvatljivi hrvatski prijevod.

(7) Zato što su to hrvatske inačice nastale nakon što su ti predmeti ušli u upotrebu pa smo se već navikli na engleske dok nisu došle hrvatske.

Sljedeći razlog prema učestalosti odgovora jest razumljivost engleske riječi spram hrvatske:

(8) Svi razumiju što želim reći, kratko i jasno.

(9) Razumljivije su široj populaciji; od niže obrazovanih do više.

(10) Zato što im znam značenje dok kod hrvatskih inačica nisam u potpunosti sigurna što znače, a neke su mi potpuno nepoznate.

2 Broj u zagradi odnosi se na broj sudionika čiji se odgovor može svrstati u danu kategoriju. 
(11) ...ne čini mi se da bi me ljudi razumjeli kad bih koristila hrvatske inačice.

(12) Današnja mladež jedino poznaje termine na engleskom jeziku. Ako hoćete biti razumljivi morate govoriti njihovim jezikom.

Treći razlog po učestalosti za uporabu engleske riječi prije hrvatske jest dojam koji hrvatska riječ ostavlja na govornika u odnosu na englesku; sudionici su mahom govorili o tome kako im engleske riječi odnosno hrvatske zamjene - zvuče. Radi preglednosti i jednostavnosti, u tablici 10 navodimo abecedni popis riječi koje su sudionici upotrijebili kako bi opisali dojam odnosno zvučnost prevedenica i anglizama. Više su, dakle, govorili o tome kako zvuče prevedenice negoli anglizmi pri objašnjavanju zašto prednost daju riječima iz engleskoga.

Tablica 10. Riječi kojima su sudionici opisivali zvučnost hrvatskih i engleskih riječi

\begin{tabular}{|c|c|}
\hline Prevedenice zvuče: & Anglizmi zvuče: \\
\hline $\begin{array}{l}\text { apsurdno, arhaično, besmisleno, bezvezno, blesavo, čudno, } \\
\text { glupo, grozno, isforsirano, izmišljeno, izvještačeno, } \\
\text { katastrofa, komično, komplicirano, loše, nakaradno, } \\
\text { nametnuto, nedovoljno vjerodostojno, neinteligentno, } \\
\text { neobično, neprihvatljivo, neprikladno, neprirodno, } \\
\text { nezgrapno, novotvoreno, pogrešno, presloženo, retardirano, } \\
\text { ridikulozno, smiješno, suludo, umjetno, usiljeno, užasno }\end{array}$ & $\begin{array}{l}\text { blaže, bolje, } \\
\text { jednostavnije, } \\
\text { melodičnije, } \\
\text { normalnije, ljepše, } \\
\text { prirodnije }\end{array}$ \\
\hline
\end{tabular}

Sudionici su upotrijebili čak 34 različita pridjeva, od kojih su neki poprilično negativni, kako bi opisali dojam koji na njih ostavlja hrvatska zamjena za anglizam.

Dio sudionika kao razlog upotrebe engleskih riječi naveo je naviku:

(13) Navika korištenja iz vremena kada se nisu često koristile hrvatske inačice.

(14) O nekim engleskim riječima (blog, isprintati) ne razmišljam kao o riječima iz engleskog jezika, pa ih koristim po navici...

(15) Stvar navike. Bez razmišljanja koristim engleske riječi. 
Sličan broj sudionika navodi da su skloniji upotrjebljavati anglizme jer je hrvatski prijevod neadekvatan:

(16) Zato jer su hrvatski prijevodi uglavnom loši.

(17) Hrvatske inačice nekih engleskih riječi nisu jednoznačne, postoji mogućnost da se krivo protumače.

(18) Jednoznačne su. Link znači točno i jedino poveznicu na internetsku stranicu. Poveznica je višeznačna riječ, može značiti svašta. Apdejtati nikad ne bih rekla, ali bome ni posuvremeniti. Ima krasna uvriježena riječ - ažurirati.

(19) Osvježiti umjesto posuvremeniti, virusni mi ima sasvim drugi kontekst... neki prijevodi ne čine se baš uspješni.

(20) Neki prijevodi bitno mijenjaju značenje (npr. virusni video $i$ viralni video).

(21) Nepoznat mi je pojam „virusni video” i totalno promašen. Virus je vezan uz zarazu, pa bi otvaranjem takvog videa značilo da će doći do zaraze uređaja računalnim virusom.

Određeni sudionici tvrde da razlog njihovoj upotrijebi anglizama leži u prirodi posla koji obavljaju:

(22) Na radnom mjestu se služim engleskim jezikom.

(23) Konkretno u mom poslu, zbog lakšeg sporazumijevanja prilikom korištenja predefinirane terminologije.

Manji broj sudionika navodi da češće upotrjebljava engleske riječi jer su upravo njima izloženiji:

(24) Vjerojatno zato sto mi je na kompu, tabletu, mobitelu, tvu više manje sve podešeno na engleski jezik.

(25) Jer je svijet više povezaniji nego ikada i svi pričaju engleski te smo bombardirani engleskim jezikom svaki dan pa stoga riječi koje čujemo na engleskom su prirodne kao i hrvatski.

(26) Stalna izloženost engleskom jeziku preko raznih medija (televizija, radio, emisije, filmovi, društvene mreže, razne internet stranice)... 
Dinamična priroda jezika razlog je koji navodi tek dvanaest sudionika:

(28) Zato što je jezik živ i fleksibilan.

(29) Jedna od karakteristika govornoga jezika je da evoluira $i$ apsorbira riječi iz drugih jezika. Svaki pokušaj uplitanja jezikoslovaca smatram neprirodnim i forsiranjem (to što postoje stare hrvatske riječi koje mogu poslužiti ili se traže riječi koje su ili zvuče hrvatski za nešto ima već ime, ne smatram dobrim razlozima).

(30) Jezikje fluidan, u njega stalno ulaze nove riječi. Hrvatski, kao $i$ drugi jezici, ima posuđenice/tudice $i$ iz drugih jezika, primjerice koristimo turcizme, germanizme itd. U novije vrijeme u hrvatski tako ulaze anglizmi (osobito iz tehnološke sfere) te smatram da ih je normalno prihvatit kao dio jezika, kao sto smo to učinili i s ostalim tudicama. Uostalom, i u, primjerice, engleskom jeziku (kao i svim jezicima) ima tudica, npr. latinizama, germanizama itd. Ako ćemo „čistiti” jezik od anglizama, tada bismo morali isto učiniti i s turcizmima itd.

Konačno, kod petero sudionika možemo iščitati svojevrstan otpor percipiranom nametanju hrvatskih zamjena:

(31) Zato jer nisu umjetne himere nametane od strane lingvističkih autoriteta (poput slikokaz i zrakomlat).

(32) Nove hrvatske kovanice za tehnološke izume su mi jako odbojne, vjerojatno zato jer mi je odbojan umjetan i nasilni trend pravljenja hrvatskog nekim „svojim” jezikom u kojemu se briše sva povijest, svi utjecaji vremena $i$ društvenih zbivanja.

(33) Neke riječi u ovom novo hrvatskom vuku porijeklo iz NDH, te su mi zbog toga odbojne, a osim toga puno su mi bliže riječi iz hrvatsko-srpskog jezika nego ovog novokomponiranog hrvatskog.

\subsubsection{Prihvatljivost hrvatskih zamjena spram anglizama}

$\mathrm{Na}$ česticu „Ako su Vam neke hrvatske inačice prihvatljivije od drugih, molim Vas ukratko obrazložite zašto." odgovorilo je 327 sudionika, a njihove 
smo odgovore svrstali u osam kategorija sa sljedećim nazivima: razumljivost (89), raširenost uporabe (75), njegovanje jezika (46), dojam (44), formalnost (29), poznatost otprije (21), posao (13) te navika (10). Zanimljivo je da je dio kategorija istovjetan onima u prethodnome odjeljku, no pri davanju prednosti hrvatskim riječima javljaju se i neki drugi razlozi, a neki razlozi koji su postojali za preferiranje anglizama - nestaju.

Najviše sudionika upotrjebljava hrvatske riječi onda kada su razumljivije od engleskih:

(34) Neke engleske riječi imaju sasvim adekvatan hrvatski prijevod $i$ engleziranje je nepotrebno prenemaganje.

(35) Hrvatske riječ jasnije su većini govornika i nisu ograničene samo na mlađu populaciju.

(36) Hrvatske inačice mi omogućuju preciznije izražavanje, a može me razumjeti veći broj ljudi.

Značajan broj sudionika koji su odgovorili na gore navedeno pitanje prednost daje hrvatskoj riječi zbog raširenosti uporabe:

(37) Neke su mi hrvatske inačice prihvatljivije od drugih zato sto se učestalije koriste.

(38) Neke su zaživjele u jeziku, pa su mi ipak draže od engleskih.

(39) „Ispisati”, „preuzeti”, „kupnja/kupovina” postojeće su i općeprihvaćene riječi hrvatskoga jezika, koje su preuzele dodatna značenja vezana uz online aktivnosti.

Dio sudionika smatra da se uporabom hrvatskih zamjena za engleske riječi njeguje hrvatski jezik:

(40) Smatram da je potrebno njegovati hrvatski jezik, posebice u formalnoj komunikaciji, te ga proširivati novim riječima koje ce popratiti suvremene promjene.

(41) Nepotrebnim korištenjem stranih riječi osiromašujemo hrvatski jezik i ugrožavamo njegovu egzistenciju.

(42) Hrvatski jezik izumire i treba ga njegovati, a to uključuje $i$ korištenje naših pravilno tvorenih riječi. 
Određeni sudionici koristit će hrvatsku inačicu onda kada ona ostavlja dobar dojam, odnosno kada ne zvuči loše:

(43) Neke hrvatske inačice dobro zvuče (poput privitak).

(44) Kupnja ili kupovina mi je prirodnija riječ od shopinga. Shoping zvuči kao da se netko pravi važan.

(45) Kad imamo riječ koja je jasna a da ne zvuči bedasto, dapače.

Dio je sudionika percipirao da odabirom hrvatske riječi postižu veći stupanj formalnosti odnosno službenosti:

(46) ...u većini slučajeva u formalnim situacijama koristim hrvatske nazive jer mi zvuče profesionalnije i ozbiljnije.

(47) Engleske riječi djeluju neozbiljno u službenim dopisima.

(48) Korištenje hrvatskih inačica u gore navedenim situacijama pospješuje formalnost u komunikaciji.

Neki su sudionici skloni upotrjebljavati hrvatske riječi onda kada su im one poznate otprije:

(49) Prihvatljivije su one koje su nam poznate od ranije.

(50) To su uglavnom riječi koje su prije postojale u jeziku, samo se primjenjuju u novom kontekstu.

(51) Kupovina nije nešto što je došlo s dobom interneta, imamo riječ za to već odavno.

(52) Riječi poput kupovina/kupnja, privitak i slične dio su standardnog jezika te im je samo pridodano novo značenje što ih ne čini odbojnima govornicima, za razliku od novih riječi, kao npr. slikokaz.

Nekoliko sudionika radije koristi hrvatske inačice negoli anglizme zbog posla:

(53) Predajem Hrvatski jezik pa sam itekako osviještena o potrebi uklanjanja tuđica.

(54) Kao pravnik koristim izraze iz pravnih propisa. 
Najmanji je broj sudionika naveo da je razlog uporabe hrvatskih riječi naspram engleskih u navici:

(55) Na neke sam se navikla, npr. privitak. Na neke ne mogu ni zamisliti da se naviknem, npr. posuvremeniti.

(56) Sve je samo stvar navike. Prihvatim obično ono što prvo naučim.

U tablici 11 vidi se da najviše sudionika kao razlog upotrebe anglizama odnosno prevedenica navodi raširenost uporabe i razumljivost. Drugim riječima, koristit će riječ za koju smatraju da je u široj uporabi i da će ih stoga većina sugovornika razumjeti. Važan čimbenik pri odlučivanju o tome koju riječ upotrijebiti svakako je i dojam koji riječ ostavlja na govornika, odnosno kako riječ zvuči - treći je to razlog po učestalosti za uporabu anglizama, a četvrti za uporabu prevedenica.

Tablica 11. Razlozi za davanje prednosti anglizmima odnosno prevedenicama, prema učestalosti

\begin{tabular}{|l|l|}
\hline $\begin{array}{c}\text { Razlozi za davanje prednosti } \\
\text { anglizmima }\end{array}$ & \multicolumn{1}{|c|}{$\begin{array}{c}\text { Razlozi za davanje prednosti } \\
\text { prevedenicama: }\end{array}$} \\
\hline 1. raširenost uporabe & 1. razumljivost \\
\hline 2. razumljivost & 2. raširenost uporabe \\
\hline 3. dojam & 3. njegovanje jezika \\
\hline 4. navika & 4. dojam \\
\hline 5. neadekvatan prijevod & 5. formalnost \\
\hline 6. posao & 6. poznatost \\
\hline 7. izloženost & 7. posao \\
\hline 8. priroda jezika & 8. navika \\
\hline 9. otpor & - \\
\hline
\end{tabular}

3 Podsjetimo, Drljača Margić (2011) navela je sljedećih četrnaest razloga posuđivanja i uporabe anglizama: popunjavanje leksičke praznine, izloženost anglizmima, praktičnost, privlačnost, prestiž, neutralnost, preciznost, potpunost opisa, kolokacijski potencijal, međunarodni status, izražavanje identiteta, ostvarivanje simboličke funkcije, stvaranje stranoga ozračja te igra riječima. 


\section{Diskusija}

Kvantitativna je analiza pokazala da je jezična kultura, kako se poima u ovome radu, viša, i to statistički značajno, kod žena $(3,44)$ u usporedbi s muškarcima $(3,08)$. Nadalje, Koeficijent jezične kulture raste s dobi, pa se oni od 20 godina ili mlađi $(2,45)$ statistički značajno razlikuju od svih ostalih skupina, primjerice najbrojnije od 31 do 50 godina $(3,42)$. Koeficijent raste i s obrazovanjem pa će oni sa završenom visokom ili višom školom $(3,29)$, fakultetom $(3,46)$ ili poslijediplomskim studijem $(3,41)$ imati statistički značajno viši KJK od onih sa srednjoškolskim obrazovanjem $(2,96)$. Odgojno-obrazovni radnici imaju statistički značajno viši KJK $(3,50)$ od svih ostalih skupina zanimanja, osim novinara i urednika $(3,58)$, ali razlika između potonje skupine i drugih nije uvijek statistički značajna. $\mathrm{Na}$ temelju napisanoga možemo pretpostaviti da je jezična kultura složena ideja te da na razinu jezične kulture utječe više čimbenika.

S obzirom na Likertovu skalu od 1 do 5 za procjenu vjerojatnosti uporabe prevedenica, teško je pronaći skupinu sudionika, a s obzirom na ispitivane varijable, u kojoj srednja vrijednost prelazi 3 i stoga ide u smjeru veće vjerojatnosti uporabe. Naime, Koeficijent (vjerojatnosti) uporabe prevedenice jest statistički značajno viši kod žena $(2,76)$ negoli muškaraca $(2,58)$, ali je i dalje ispod 3 . KUP ne prelazi tu vrijednost ni u slučaju kategorija dobi, osim kod sudionika starijih od 61 godine $(3,14)$; kod najbrojnije skupine sudionika u vidu dobi, od 31 do 50 godina, KUP iznosi 2,71. Najviši KUP s obzirom na stupanj obrazovanja imaju sudionici s fakultetom $(2,78)$, što je statistički značajno više od onih sa srednjom školom $(2,40)$. Koeficijent (vjerojatnosti) uporabe prevedenice ne prelazi vrijednost 3 ni u slučaju različitih zanimanja; najviši KUP imaju odgojnoobrazovni radnici $(2,82)$, ali to nije statistički značajna razlika u odnosu na sva druga zanimanja. Primjerice, statistički je to značajno više od KUP-a novinara i urednika, a koji iznosi 2,44, ili pak radnika kojima jezik nije primaran interes, koji ujedno imaju i najniži KUP od 2,31. Konačno, skupina u kojoj vrijednost KUP-a prelazi 3 jesu sudionici koji su izjavili da ne znaju engleski jezik te iznosi 3,04 i statistički je značajno viši od KUP-a sudionika koji znaju engleski $(2,72)$. Uzevši u obzir navedeno, čini se da su prevedenice za uporabu u formalnome kontekstu općenito najprihvatljivije najstarijim sudionicima te sudionicima koji ne znaju engleski jezik. Za ostale skupine sudionika, malo je vjerojatno ili nije uopće vjerojatno da bi dane prevedenice upotrijebili u formalnome kontekstu. 
Imajući u vidu napisano, odgovor na prvo istraživačko pitanje jest da među sudionicima postoje razlike s obzirom na spol, dob, stupanj obrazovanja, zanimanje, znanje engleskoga, ali ne i broj stranih jezika u vidu povezanosti s dvama koeficijentima.

Kvalitativnom smo analizom došli do odgovora na četvrto istraživačko pitanje. Naime, kvalitativna je analiza pokazala da sudionici imaju različite razloge za davanje prednosti anglizmima odnosno prevedenicama. Zanimljivo, razlog za uporabu anglizama nije, kao što su to percipirali neki jezikoslovci, lijenost ili pomanjkanje jezične kulture; „lijenost” odnosno navika tek je jedan od razloga, i to ne najučestaliji. Očekivano, govornici žele biti shvaćeni, pa je raširenost uporabe i razumljivost anglizama spram hrvatskih prevedenica ono što govornike motivira u uporabi riječi iz engleskoga jezika. Dakako, vrijedi i obratno, pa ako je prevedenica razumljiva, odnosno ako je semantički transparentna, te je već raširena u uporabi, tada će je i govornici biti spremni upotrijebiti.

Prevedenica ne može postati raširena u uporabi ako govornik smatra da ne zvuči dobro ili da ne prenosi značenje u istoj mjeri kao anglizam. Na raširenost se uporabe ne može utjecati izravno, ali se svakako može nastojati dati priliku govornicima da daju svoje mišljenje o tomu prenosi li prevedenica doista značenje koje treba prenijeti i zvuči li uopće dobro govornicima prije negoli je se promiče u jezičnim savjetnicima ili bilježi u rječnicima hrvatskoga standardnog jezika. ${ }^{4} \mathrm{O}$ tome kako uključiti govornike bit će riječi u zaključcima koji slijede.

$\mathrm{Na}$ temelju rezultata kvantitativne i kvalitativne analize, a kao odgovor na drugo odnosno treće istraživačko pitanje, predlažemo sljedeću ljestvicu prihvatljivosti prevedenica, od najprihvatljivijih do najmanje prihvatljivih ili čak neprihvatljivih:

1. Prevedenica je jednorječni izraz koji već postoji u hrvatskome jeziku, dio je aktivnoga rječnika, te mu je pridodano novo značenje (npr. preuzeti, privitak).

4 Zanimljivo, u Velikome rječniku hrvatskoga standardnog jezika (Jojić 2015) slikokaz se definira prvo kao zastarjelica za kino, a potom kao neologizam sa značenjem „ilustrativna pratnja nekog izlaganja..." (1424), bez ikakve poveznice s riječju slajd. Riječ slajd ipak je zabilježena u tome rječniku, ali se dovodi u sinoniman odnos s riječju dijapozitiv (!) i ne upućuje na slikokaz. 
2. Prevedenica je višerječni izraz koji se sastoji od riječi koje već postoje u hrvatskome jeziku i dio su aktivnoga rječnika (npr. mrežni seminar).

3. Prevedenica je novotvoreni kalk (npr. višezadaćnost) ili se percipira kao novotvoreni kalk (npr. slikokaz, koji postoji otprije, ali nije dio aktivnoga rječnika hrvatskoga jezika).

Lako je shvatiti da su govornicima kao zamjene za anglizme prihvatljivije one riječi koje već upotrjebljavaju te im samo valja pridodati novo značenje. Ako to nije moguće, anglizam bi se mogao zamijeniti višerječnim opisom, gdje su sve riječi govornicima poznate i stoga je lakše shvatiti značenje. Valja imati na umu da će se govornici vjerojatno voditi načelom jezične ekonomičnosti pa će prednost dati kraćemu izrazu (npr. blog naspram internetski dnevnik). Usto, ako govornici smatraju da riječ odnosno sintagma ne prenosi značenje kao anglizam, neće je upotrjebljavati, bez obzira na to jesu li sastavnice značenjski transparentne (npr. virusni video). Posljednja je mogućnost kovanje kalkova koja je i najmanje poželjna s obzirom na to da kalkovi nisu semantički transparentni kao druga dva tipa prevedenica i da na mnoge govornike ostavljaju negativan dojam. Ipak, valja reći da kalkovi neće možda uvijek imati takav učinak; moguće je da negativan dojam ostavljaju na govornike koji se sjećaju jezičnoga čišćenja 1990 -ih te ih odviše podsjećaju na vrijeme vrtoleta i dalekovidnice. U svakome slučaju, smatramo da bi oni koji predlažu zamjene za anglizme danas trebali na umu imati i ovu ljestvicu prihvatljivosti.

Sudeći prema rezultatima prethodnih istraživanja (Drljača Margić 2012; Matić 2017), pa tako i ovoga, govornici jesu otvoreni uporabi hrvatskoga jezika, ali očigledno je da nisu uvijek upoznati s mogućim zamjenama ili nisu njima zadovoljni. S obzirom na to da iznenađujuće velik broj sudionika (74,48 \%) jezične savjete smatra korisnima i da još više sudionika prati emisije s jezičnim savjetima $(80,67 \%)$ te da gotovo polovica sudionika $(49,55 \%)$ ne smatra engleski jezik prestižnijim od hrvatskoga, ne preostaje nam nego zaključiti da problem prihvatljivosti prevedenica ne leži u primateljima jezičnih savjeta, nego u davateljima.

$\mathrm{Na}$ ovome se mjestu valja zapitati i je li uvijek potrebno ponuditi hrvatsku zamjenu za anglizam. Muhvić-Dimanovski (1986: 252) smatra da nije nužno stvarati prevedenice za one riječi koje se „po svojoj fonološkoj i morfološkoj strukturi uklapaju u naš jezik” već samo u slučaju kada strana riječ „zaista odudara od našeg jezičnog sustava ili gdje čak postoji domaća 
riječ koja jednako tako dobro može izraziti sadržaj posuđenice”. Nadalje, Peti-Stantić (2013) propituje i snažno kritizira načelo „domaće je najbolje” kada je riječ, konkretno, o intervencijama u terminologiju u vidu zamjenjivanja internacionalizama (i anglizama) hrvatskim inačicama; za određene zamjene ustvrđuje da su „mehaničke, bez promišljanja o prihvaćenosti postojećih termina" (35). Sličan stav odražavaju i riječi jednoga sudionika našega istraživanja u vezi s prihvaćenim anglizmima: „Ako se daju napisati i deklinirati/konjugirati/komparirati, ne vidim razloga za usiljene prijevode". Ovdje valja podsjetiti na podatak da više od petine sudionika smatra da prevedenice udomaćenih riječi iz engleskoga jezika nisu potrebne.

S gore navedenim stavovima složit ćemo se djelomično. Naime, smatramo da ne postoji ništa loše u tome da se osmišljavaju hrvatske zamjene za anglizme, ali pod uvjetom da se proces osmišljavanja otvori većemu broju govornika i da se prevedenice ne nameću kao norma; o tome hoće li anglizam ili prevedenica postati dio norme treba prepustiti samim govornicima, odnosno uzusu na kojemu bi se u konačnici norma i trebala temeljiti. Uostalom, kako prepoznaje Granić (2009: 430), jezična praksa „koja ipak na kraju 'presuđuje' u korist ove ili one riječi, odnosno jezične konstrukcije koja postaje općeprihvaćena, zasad potvrđuje da sve nametnuto, paranormativno u novogovoru zaista ostaje samo u užem izboru uže jezične zajednice."

\section{Zaključci}

Normu je potrebno učiniti otvorenijom uzusu (Patekar 2017), a prvi korak k tomu jest uporaba korpusa koji sadržavaju pisani i govoreni jezik. Uporabom bi se korpusa u leksikografskome i jezičnosavjetodavnome radu izbjegla situacija u kojoj se hrvatski standardni jezik nalazi u rukama pojedinaca (Patekar 2015). Nažalost, trenutno ne postoji reprezentativan korpus hrvatskoga jezika. Stoga je preporučljivo da oni koji osmišljavaju prevedenice promisle o drugim načinima kojima bi govornike mogli uključiti u normiranje hrvatskoga standardnog jezika.

Primjerice, s obzirom na to da se Institut za hrvatski jezik i jezikoslovlje sve više okreće digitalnomu, pa pružaju raznovrsne informacije na mrežnim stranicama i putem programa za mobilne uređaje (Pravopis.hr, 555+ savjeta, Bolje.hr itd.), s tehničke strane ne bi bilo zahtjevno omogućiti korisnicima da izraze sviđanje ili nesviđanje u vezi s određenim sadržajem ili da biraju 
jednu od ponuđenih inačica prevedenice ${ }^{5}$. Muhvić-Dimanovski i Horvat (2008: 24) smatraju da uključivanje govornika u osmišljavanje novih riječi može donekle pomoći u stvaranju srednjega puta između tvrdoga purizma i odveć popustljivih stavova prema stranim riječima. Ako se to čini preširoko, moguće je govornike uključiti u normiranje jezika putem, na primjer, fokusgrupa. U svakome slučaju, govornike treba uključiti jer, kao što su MuhvićDimanovski i Horvat (2008: 24-25) uočile u svojoj analizi stavova o natjecanjima za najbolju novu riječ, „iako su mnoge nove riječi ispunile potrebne kriterije [tvorbenosti, semantičnosti], nisu uspjele biti dovoljno privlačnima i vjerojatno nikada neće postati dio općega vokabulara” (autorov prijevod). Stav o „privlačnosti” riječi ne bi se smio temeljiti na jezičnome osjećaju pojedinca.

Pri osmišljavanju prevedenica i odlučivanju o normativnoj inačici, jezikoslovci bi i drugi stručnjaci pored razmatranja temeljnih načela jezične pravilnosti (Pranjković 1996) i osnovnih terminoloških načela (Frančić, Hudeček i Mihaljević 2006) u obzir trebali uzeti i rezultate ovoga istraživanja koji upućuju na postojanje stupnjeva prihvatljivosti prevedenica - od riječi koja otprije postoji u aktivnome rječniku hrvatskoga jezika, preko sintagme koja se sastoji od takvih riječi, do kalkova kao najmanje semantički transparentnih. Ipak, navedenu bi ljestvicu prihvatljivosti svakako valjalo provjeriti i potvrditi u daljnjim istraživanjima stavova govornika prema hrvatskim zamjenama za anglizme. Pored provjere ljestvice prihvatljivosti, u daljnjim bi istraživanjima trebalo težiti uzorku reprezentativnijemu za opću populaciju.

Zaključno, valja reći da smo kao jezikoslovci često skloni jezik prisvojiti sebi i svojoj grani, zaboravljajući da jezik pripada i drugim granama i poljima, a ponajviše, ipak, pripada - govornicima. Jezik možemo opisivati, a katkad i proučavati, ne zamarajući se govornicima, analizirajući rječnike, gramatike, knjige; no, intervenirati u jezik i očekivati da govornici bespogovorno intervenciju prihvate, a da te iste govornike u taj proces nismo uključili, nije pristup na kojemu bi se trebala temeljiti hrvatska jezična politika. U konačnici, govornici nisu, kao što bi se moglo pomisliti na temelju djelovanja dijela jezikoslovaca, nuspojava jezika - dapače, oni su bit jezika.

5 Na mrežnim stranicama „Bolje je hrvatski” (http://bolje.hr/) omogućeno je komentiranje savjeta odnosno prevedenica, što je svakako dobrodošlo, ali ne omogućuje kvantificiranje povratnih informacija kao što bi se moglo učiniti s ljestvicom na kojoj bi korisnici izražavali koliko im se zamjena (ne) sviđa. 


\section{Literatura}

Babić, Stjepan (2004) Hrvanja hrvatskoga: hrvatski u koštacu sa srpskim i u klinču s engleskim, Školska knjiga, Zagreb.

Blagus Bartolec, Goranka, Lana Hudeček, Željko Jozić, Ivana Matas Ivanković, Milica Mihaljević (2016) 555 jezičnih savjeta, Institut za hrvatski jezik i jezikoslovlje, Zagreb.

Bogunović, Irena, Bojana Ćoso (2013) „Engleski u hrvatskome: znanstveni izričaj biomedicine i zdravstva", Fluminensia, 25, 2, 177-191.

Brdar, Irena (2010) „Engleske riječi u jeziku hrvatskih medija”, Lahor, 10, 217-232.

Drljača, Branka (2006) „Anglizmi u ekonomskome nazivlju hrvatskoga jezika i standardnojezična norma", Fluminensia, 18, 1, 65-85.

Drljača Margić, Branka (2009) „Latentno posuđivanje u hrvatskome i drugim jezicima - posljedice i otpori", Rasprave Instituta za hrvatski jezik i jezikoslovlje, 35, 1, 53-71.

Drljača Margić, Branka (2011) „Leksički paralelizam: je li opravdano govoriti o nepotrebnim posuđenicama (engleskoga podrijetla)?", Fluminensia, 23, 1, 53-66.

Drljača Margić, Branka (2012) „Stavovi govornika prema zaštiti hrvatskoga jezika od utjecaja engleskoga i promicanju hrvatskih zamjena za anglizme", Zbornik radova s međunarodnoga znanstvenog skupa Peti hrvatski slavistički kongres održanoga u Rijeci od 7. do 10. rujna 2010, ur. Marija Turk i Ines Srdoč-Konestra, Ines (ur.), Rijeka, 387-394.

Filipović, Rudolf (1986) Teorija jezika u kontaktu. Uvod u lingvistiku jezičnih dodira, Jugoslavenska akademija znanosti i umjetnosti i Školska knjiga, Zagreb.

Filipović, Rudolf (1990) Anglicizmi u hrvatskom ili srpskom jeziku: porijeklorazvoj-značenje, Školska knjiga, Zagreb.

Frančić, Anđela, Lana Hudeček, Milica Mihaljević (2006) Normativnost $i$ višefunkcionalnost u hrvatskome standardnom jeziku, Hrvatska sveučilišna naklada, Zagreb.

Gradečak-Erdeljić, Tanja, Mirna Varga (2009) „Jezik kao izvozni proizvod engleski eufemizmi u hrvatskom političkom diskursu", Jezična politika i jezična stvarnost, ur. Jagoda Granić, Zagreb, 339-348.

Granić, Jagoda (2009) „Jezična stvarnost: novogovor u užem izboru”, Jezična politika i jezična stvarnost, ur. Jagoda Granić, Zagreb, 423-432. 
Halonja, Antun, Milica Mihaljević (2012) „Novotvorenice u računalnome nazivlju”, Jezik: časopis za kulturu hrvatskoga književnog jezika, 59, 3, 87-94.

Horvat, Marijana, Barbara Štebih Golub (2010) „Posljedice internacionalizacije u hrvatskome jeziku", Rasprave Instituta za hrvatski jezik i jezikoslovlje, 36, 1, 1-21.

Hudeček, Lana, Milica Mihaljević (2005) „Nacrt za višerazinsku kontrastivnu englesko-hrvatsku analizu", Rasprave Instituta za hrvatski jezik i jezikoslovlje, 31, 107-151.

Hudeček, Lana, Milica Mihaljević (2009) Jezik medija. Publicistički funkcionalni stil, Hrvatska sveučilišna naknada, Zagreb.

Hudeček, Lana; Milica Mihaljević (ur.) (2012) Školski rječnik hrvatskoga jezika, Institut za hrvatski jezik i jezikoslovlje i Školska knjiga, Zagreb.

Jojić, Ljiljana (ur.). (2015) Veliki rječnik hrvatskoga standardnog jezika, Školska knjiga, Zagreb.

Matić, Daniela (2015) „Percepcija hrvatskih studenata računarstva o prihvatljivosti engleskoga elementa u glagolima, glagolskim imenicama i jukstaponiranim leksičkim segmentima u hrvatskim tekstovima iz područja računalnih i komunikacijskih tehnologija", Od teorije do prakse u jeziku struke, ur. Vesna Cigan i Darija Omrčen, Zagreb, 65-81.

Matić, Daniela (2017) „Perception of the English element in the scientific register of Croatian ICT universtiy educational material with graduate ICT students", Jezikoslovlje, 18, 2, 319-345.

Mihaljević, Milica (1999) „Kako se na hrvatskome kaže www?”, Rasprave Instituta za hrvatski jezik i jezikoslovlje, 25, 233-248.

Muhvić-Dimanovski, Vesna (1986) „O paralelnoj upotrebi posuđenica i njihovih prevedenica”, Filologija, 14, 247-253.

Muhvić-Dimanovski, Vesna (1992) „Prevedenice - jedan oblik neologizama”, Rad Hrvatske akademije znanosti i umjetnosti, 446, 94-205.

Muhvić-Dimanovski, Vesna (2004) „New Concepts and New Words - How Do Languages Cope With the Problem of Neology", Collegium antropologicum, 28, 1, 139-146.

Muhvić-Dimanovski, Vesna, Anita Skelin Horvat (2006) „O riječima stranoga podrijetla i njihovu nazivlju”, Filologija, 46-47, 203-215. 
Muhvić-Dimanovski, Vesna, Anita Skelin Horvat (2008) „Contests and nominations for new words - why are they interesting and what do they show", Suvremena lingvistika 65, 1, 1-26.

Nikolić-Hoyt, Anja (2009) „Između jezične politike i jezične stvarnosti: Ah, taj engleski!", Jezična politika i jezična stvarnost, ur. Jagoda Granić, Zagreb, 491-498.

Opačić, Nives (2007) „Prodor engleskih riječi u hrvatski jezik”, Jezik: Časopis za kulturu hrvatskoga književnog jezika, 54, 1, 22-27.

Opačić, Nives (2012) Hrvatski ni u zagradama. Globalizacijska jezična teturanja, Hrvatska sveučilišna naklada, Zagreb.

Opačić, Nives (2015) Reci mi to kratko i jasno. Hrvatski za normalne ljude. 2. prošireno izdanje, Znanje, Zagreb.

Patekar, Jakob (2015) „U potrazi za značenjem: čitak i čitljiv u normi i uporabi", Jezikoslovlje, 16, 2-3, 337-356.

Patekar, Jakob (2017) „Odnos norme i uzusa na primjeru paronima”, Rasprave: Časopis Instituta za hrvatski jezik i jezikoslovlje, 43, 1, 163-179.

Peti-Stantić, Anita (2013) „Domaće je najbolje”, Javni jezik kao poligon jezičnih eksperimenata, ur. Barbara Kryżan-Stanojević, Zagreb, 39-51.

Peti-Stantić, Anita; Jelena Tušek, Marija Horniš (2009) „Govorimo jezikom menadžera - govorimo hrvatski”, Jezična politika i jezična stvarnost, ur. Jagoda Granić, Zagreb, 184-194.

Pranjković, Ivo (1996) „Temeljna načela jezične pravilnosti”, Kolo, 4, 5-12.

Pritchard, Boris (1996) „Anglicizmi u poslovnim komunikacijama u hrvatskom pomorstvu", Suvremena lingvistika, 41-42, 1-2, 529-543.

Skelin Horvat, Anita (2004) „Posuđivanje u hrvatski jezik u dvama razdobljima", Suvremena lingvistika, 57-58, 1-2, 93-104.

Sočanac, Lelija (1993) „O nekim anglicizmima i pseudoanglicizmima u rječnicima hrvatskoga književnog jezika”, Filologija, 22-23, 225-228.

Sočanac, Lelija (2009) „Utjecaj engleskog jezika na jezičnu politiku i planiranje", Jezična politika i jezična stvarnost, ur. Jagoda Granić, Zagreb, 717-722.

Škifić, Sanja; Emilija Mustapić (2012) „Anglizmi i hrvatsko računalno nazivlje kroz prizmu jezičnoga konflikta i jezične ideologije", Jezikoslovlje, 13, 3, 809-839. 
Težak, Stjepko (2004) Hrvatski naš (ne)podobni, Školske novine, Zagreb.

Vilke, Mirjana, Marta Medved Krajnović (2006) „Govorite li hrengleski?”, Jezik i mediji. Jedan jezik - više svjetova, ur. Jagoda Granić, ZagrebSplit, 769-778.

\section{SUMMARY}

Jakob Patekar

THE ACCEPTABILITY OF LOAN TRANSLATIONS AS SUBSTITUTES FOR ANGLICISMS

At the beginning of the $21^{\text {st }}$ century, a change in discourse could be noticed in Croatia - no longer were linguists talking about the Croatian language borrowing words from English, but about English words penetrating into Croatian. The age of the Internet and electronic media has made it possible for Croatian speakers to come into contact with English words more directly and much faster than before and hence to include English words in their communication faster. A number of linguists and other experts raised the alarm that Croatian is under siege and thus started to defend it by offering Croatian substitutes for anglicisms. The aim of this paper is to investigate the attitudes of Croatian speakers towards anglicisms and Croatian loan translations. Based on an online survey completed by 1340 participants, the acceptability of a certain number of Croatian substitutes for anglicisms is analysed. Furthermore, an analysis was carried out in view of the participants' reasons for preferring either English or Croatian words. Quantitative and qualitative analysis has shown that there are differences in the acceptability of certain loan translations and that speakers have a variety of reasons for using either the English or the Croatian word. The conclusion is that those who offer Croatian substitutes for anglicisms and design Croatian language policy need to take into account the speakers' attitudes as an important factor.

Key words: Anglicisms; loan translations; norm; usage; purism; language policy 